\title{
Suicidal Competence and the Patient's Right to Refuse Lifesaving Treatment
}

In April 1986, Elizabetlı Bouvia won a court order permitting lier to refuse medical efforts to preserve her life. ${ }^{1}$ Her case raised hard questions concerning the limits of a coinpetent adult's riglit to refuse lifesaving medical treatment. Although Bouvia subsequently decided to postpone her deatll, ${ }^{2}$ her case will reinam important, as patients and courts confront situations that raise similar legal and moral questions about the extent of patients' autonomy and the limits of medical paternalism. ${ }^{3}$

At the tiine of her legal victory, Bouvia was a twenty-eight-year-old woman afflicted with cerebral palsy and degenerative arthritis. ${ }^{4}$ She was almost coinpletely paralyzed, suffered contimual pain, and needed constant nursing care. ${ }^{5}$ Althougl not terminally ill, she had no chance of recovery and would need continual medical care for the fifteen or twenty years her doctors expected her to live. ${ }^{6}$ Articulate and intelligent, Bouvia had earned a college degree before lier illness inade an active life impossible. ${ }^{7}$ Even before her illness becaine so debilitating, she apparently liad not liad an easy life; she had been left by her husband and liad suffered a miscarriage. ${ }^{8}$ By 1986 , her family and friends were no longer able to house and care for her. ${ }^{9}$

Bouvia's legal fight began in 1983, when slie voluntarily entered the psychiatric unit of a Califormia county hospital seeking "just [to] be left alone and not bothered by friends or family or anyone else and to ulti-

1. Bouvia v. Superior Court, 179 Cal. App. 3d 1127, 225 Cal. Rptr. 297 (1986).

2. See L.A. Times, Oct. $8,1986, \S 2$, at 3 , col. 2 (quoting one of Bouvia's attorneys as stating that suicide, in the "cold environment" of a county hospital, remains "an option [Bouvia] holds in abeyance," because "she wants to go out with some dignity").

3. At least two cases raising similar issues have been decided since Bouvia. In Brophy v. New England Sinai Hosp., 398 Mass. 417, 497 N.E.2d 626 (1986), a comatose patient's wife sought successfully on his behalf to have his feeding tubes removed because he had previously indicated that he would not want treatment in such circumstances. In an unreported Colorado case, a competent but paralyzed patient, Hector Rodas, won an injunction to compel his doctors to cease feeding him. Durango Herald, Feb. 6, 1987, at A1, col. 1; Rodas Granted Wish to Die, Grand Junction Daily Sentinel, Jan. 22, 1987, at Al, col. 2.

4. Bouvia, 179 Cal. App. 3d at 1135-36, 225 Cal. Rptr. at 299-300.

5. Id. at 1136, $225 \mathrm{Cal}$. Rptr. at 300.

6. See id. at 1142-43, $225 \mathrm{Cal}$. Rptr. at 304-05.

7. See id. at $1136,225 \mathrm{Cal}$. Rptr. at 300.

8. Id.

9. Id. 
mately starve to death." 10 There she requested a court order to prevent the hospital staff from force-feeding her. ${ }^{11}$ The court denied Bouvia's request on the grounds that her right to refuse treatment was outweighed by four important state interests: in preserving the life of a nonterminal patient, in protecting the "established ethics of the medical profession," in preventing the "devastating effect" that her choice to die would have on other patients and other handicapped people, and in preventing suicide. $^{12}$ Bouvia initiated but later abandoned an appeal froin that ruling. ${ }^{13}$ For the next two years, she stayed at various public and private facilities; a search by social workers for a place where she could live independently was unsuccessful. ${ }^{14}$

Bouvia eventually went to a county hospital near Los Angeles, where her doctors determined that she was not eating enough to sustain herself. $^{15}$ The reason for this was disputed: Bouvia clained she was physically unable to eat enough to sustain herself, but her doctors beheved that she simply chose not to eat. ${ }^{16}$ Fearing that her life was in danger, her doctors inserted a nasogastric feeding tube into her body. In doing so, they acted contrary to her express written instructions. ${ }^{17}$ Bouvia responded by requesting an injunction to compel the doctors to remove the feeding tube. ${ }^{18}$

The trial court denied the injunction, on the ground that Bouvia was not asserting in good faith her right to refuse medical treatnient, but rather was seeking the state's help in coinmitting suicide. ${ }^{19}$ On appeal,

10. Annas, When Suicide Prevention Becomes Brutality: The Case of Elizabeth Bouvia, HAstings Center ReP., Apr. 1984, at 20 (quoting Bouvia); see also Bouvia, 179 Cal. App. 3d at 1136, 225 Cal. Rptr. at 300 (stating that in 1983 Bouvia sought the right to be cared for in a public hospital while she starved herself to death).

11. See Bouvia, 179 Cal. App. 3d at 1136, 225 Cal. Rptr. at 300.

12. Annas, supra note 10, at 20 (discussing Bouvia v. County of Riverside, No. 157280 (Cal. Super. Ct. Riverside Co., Dec. 16, 1983)); Heilman \& Thompson, Tender Mercies: Health Care Dilemmas for the Courts, 7 L.A. LAw. 13, 13 (May 1984).

13. Bouvia, $179 \mathrm{Cal}$. App. 3d at 1136, 225 Cal. Rptr. at 300.

14. Id.

15. Id. at 1135, 25 Cal. Rptr. at 299-300.

16. See id. at 1136, $225 \mathrm{Cal}$. Rptr. at 300 . The trial court made apparently inconsistent findings that she was willing but unable to eat enough by spoon feeding to sustain herself, and that she was deliberately refusing nourishment to bring about her death. Id. at 1144, $225 \mathrm{Cal}$. Rptr. at 305-06. The appellate court majority interpreted these findings to mean that, while Bouvia had made an attempt at suicide by starvation in 1983, at the time of her 1986 appeal she was unable, "without artificial aids, to consume sufficient nutrients to sustain herself." Id. at 1144, $225 \mathrm{Cal}$. Rptr. at 306. However, Justice Compton's concurring opinion characterized her conduct as "ending her life by the only means she sees available-starvation." Id. at 1147, $225 \mathrm{Cal}$. Rptr. at 307 (Compton, J., concurring).

17. Id. at $1136 \&$ n.2, 225 Cal. Rptr. at $300 \&$ n.2.

18. Id. at $1134,225 \mathrm{Cal}$. Rptr. at 298.

19. Id. at $1135,225 \mathrm{Cal}$. Rptr. at 299. The trial court appears to have based its "suicide" conclusion on Bouvia's repeatedly expressed intent to die, on the fact that she was not terminally ill, 
the trial court was ordered to grant the injunction. ${ }^{20}$ The California Court of Appeal held that all competent patients, whether terminally ill or not, have the right to refuse any and all medical treatment regardless of their motives for doing so. ${ }^{21}$

The court of appeal framed the central legal issue in Bouvia as the extent of a competent adult's right to refuse lifesaving medical treatinent. ${ }^{22}$ But Bouvia and similar cases also raise broader issues concerning suicide, euthanasia, ${ }^{23}$ and the limits of state paternalism. This Comment explores the relation between refusal of treatment and suicide, and argues that when a patient's refusal of medical intervention is tantamount to suicide, the patient's right to refuse treatment should at least temporarily be restricted.

This Comment first analyzes the present doctrime established by the refusal of treatınent cases. Part II then explores the various patient interests that provide the basis for the right to refuse treatment. Parts III-V discuss the limitations on that right, mcluding the requirement of patient competence and the several countervailing state interests-including an interest in preventing suicide-that oppose the right of the competent patient to refuse treatment. Part VI argues that the state has a legitimate interest not in preventing all suicides, but ouly in preventing irrational ones and that, conversely, the values underlying the right to refuse treatment only support a right to do so competently. Thus, the crucial question is whether an arguably suicidal patient is competent. Fmally, Part VII proposes both a test for determining whether a patient's decision to refuse treatment is competent and a policy of temporarily restraining suicidal patients in order to ascertain whether they are firmly and calmly determined to die.

and on her consent only to nursing care and pain relief from the doctors and hospital staff. See id. at 1144, 225 Cal. Rptr. at 305-06.

20. Id. at 1146,225 Cal. Rptr. at 307.

21. Id. at 1137-38, 1145, $225 \mathrm{Cal}$. Rptr. at 300-01, 306. The California Supreme Court refused to review the case. L.A. Times, June $6,1986, \S 2$, at 1 , col 3. After the injunction was issued, Bouvia began to accept nourishment. N.Y. Times, Apr. 20,1986, $\S 1$, at 26, col. 1. She is, as of January 1987, still alive. She changed hospitals when doctors refused to continue high dosages of morphine for pain relief. L.A. Times, May 23, 1986, $\S 2$, at 1, col. 1. Moreover, she amended a pending lawsuit against Los Angeles County to seek $\$ 10$ million in malpractice damages against the hospital and hospital committee that had ordered force-feeding. L.A. Times, Oct. 8, 1986, § 2, at 1, col 1 .

22. See Bouvia, 179 Cal. App. 3d at 1137, 225 Cal. Rptr at 300-01.

23. The concepts of suicide and euthanasia overlap. The definition of euthanasia focuses on the assistance of a third person, and so usually excludes cases in which a patient ends his life unassisted. However, helping a patient to end his life, either by providing him with the means to kill himself or by supporting him with palliative care after withdrawing life-support, could be called either voluntary euthanasia or assisting suicide. Conversely, suicide generally excludes cases in which one person kills another with the latter's consent, and cases in which an unconscious patient is killed "mercifully." This Comment focuses on the issue of suicide-the legal and moral status of the patient's own action-but the inquiry clearly cannot be isolated from questions of euthanasia. 


\section{I \\ BACKGROUND \\ A. Terminology}

As a preliminary matter, several terms that have special meanings in the context of refusal of treatment cases slould be defined.

First, "lifesaving treatment" refers to all medical means of prolonging life, froin simple intravenous feeding to extraordinary measures such as dialysis and respirators. This definition ignores the distinction between ordinary and extraordinary means of medical treatment-a distinction that is considered crucial in soine inedical decisionmakingbecause it is not relevant in refusal of treatinent cases. ${ }^{24}$

Second, the term "terminally ill" is applied to persons who are in the process of dying, and not to those who have fatal conditions from which they eventually will die. ${ }^{25}$ Although deemed inportant by courts in soine of the earlier refusal of treatment cases, this fine distinction is no longer doctrimally relevant in the disposition of refusal of treatment cases. ${ }^{26}$

Third, the precise meaning of "coinpetence," though elusive, is integral to the suicidal refusal issue. A preliminary distinction can be made between a conscious patient, who is able to compreliend and evaluate the risks and benefits of treatment choices, and a comatose, brain-dannaged, or senile patient, who cannot even attempt to make her own decisions about medical treatment. Patients in this latter category pose problems that are beyond the scope of this Comment, which instead focuses on the riglits of coinpetent patients and patients at the boundary line between competence and incoinpetence.

Fimally, this Comment characterizes some refusals of treatment, mcluding Bouvia's, as "suicidal" because they fall within the commonly understood concept of suicide. According to that concept, one who no longer wants to live, ${ }^{27}$ and who takes definite, effective steps to end her life-whether by actively killing lerself or by avoiding available ways of preventing her own death-commits suicide. While acknowledging that some self-destructive conduct is of course ambiguous, this Comment

24. See, e.g., Barber v. Superior Court, 147 Cal. App. 3d 1006, 1018, 195 Cal. Rptr. 484, 491 (1983) (rejecting distinction in refusal of treatment context); In re Conroy, 98 N.J. 321, 370-71, 486 A.2d 1209, 1234-35 (1985) (same).

25. See, e.g., Bartling v. Superior Court, 163 Cal. App. 3d 186, 189, 209 Cal. Rptr. 220, 220-21 (1984) (although the patient had multiple incurable illnesses and was expected to live onc year or less, he was "not ... diagnosed as terminal").

26. The right to refuse treatment was expressly limited to terminal patients in some cases. See infra note 99-101 and accompanying text.

27. Suicide is thus distinct from self-sacrifice, in that its basic purpose is to achieve one's own death, and not to use one's death as a means to accomplish some other goal, such as saving another person's life or following one's religious teachings. 
refers to treatment refusals that prima facie fall within this commonsense concept of suicide as "suicidal refusals." The scope of this term, and its implications for the right to refuse treatment, are important parts of this inquiry.

\section{B. The Refusal of Treatment Cases}

Cases that have developed the refusal of treatment doctrine illustrate the various factual contexts in which suicidal refusal probleins arise. This Section discusses the most recent, relevant, and thoroughly reasoned decisions in refusal of treatment cases.

\section{Bartling v. Superior Court}

The Bouvia court, in deciding to allow Elizabeth Bouvia to refuse treatment, principally rehed on Bartling $v$. Superior Court. ${ }^{28}$ Bartling involved a seventy-year-old man who suffered from multiple nonterminal but serious illnesses and was not expected to live more than a year. ${ }^{29} \mathrm{He}$ executed various legal documents declaring his wish to be allowed to die, ${ }^{30}$ requested the withdrawal of his respirator, ${ }^{31}$ and even attempted to reinove the respirator tubes himself. ${ }^{32} \mathrm{He}$ eventually sought an injunction to coinpel doctors to remove the respirator. ${ }^{33}$ The trial court denied his request, and he and his wife filed a petition challenging the denial.

Although the patient, while still on a respirator, died on the day of the hearing, the Califorma Court of Appeal rendered a decision in order to resolve recurring issues. ${ }^{34}$ The court held that the patient should have been perınitted to order the respirator withdrawn because competent patients have a general right to decide whether or not to submit to medical treatment. ${ }^{35}$ The court mainly rehed on the constitutional right of privacy, but also referred to the common law protection against bodily invasion without consent. ${ }^{36}$

28. 163 Cal. App. 3d 186, 209 Cal. Rptr. 220 (1984). See Bouvia v. Superior Court, 179 Cal. App. 3d 1127, 1138-39, 225 Cal. Rptr. 297, 301-02 (1986).

29. Bartling, $163 \mathrm{Cal}$. App. 3d at 189, 192, 209 Cal. Rptr. at 220-21, 223.

30. Id. at 190-91, $209 \mathrm{Cal}$. Rptr. at 222 . The documents included a "living will" expressing his wish that medical care be withheld should he become terminally ill and incompetent, a Durable Power of Attorney for Health Care granting his wife the power to make medical decisions if he became incompetent (executed under CAL. Civ. CoDE $\$ \S 2430-2444$ (West Supp. 1984)), a formal declaration of his wish to end treatment and of his knowledge that this decision would result in his death, and a form releasing the doctors and hospital from all liability if they carried out his decision to stop treatment.

31. Bartling, 163 Cal. App. 3d at 190, 209 Cal. Rptr. at 221.

32. Id.

33. Id.

34. Id. at 189,209 Cal. Rptr. at 221.

35. Id. at 193-95, $209 \mathrm{Cal}$. Rptr. at 223-25.

36. Id. at 194-96, $209 \mathrm{Cal}$. Rptr. at 224-25. The court further stated that the state's recognition of these rights is expressed in the Natural Death Act, CaL. HealTh \& SAFETY CodE 
The Bartling court extended the right to refuse treatment only to patients who are competent and whose refusals are unambiguous. ${ }^{37} \mathrm{Hav}$ ing found Bartling to be competent, the court then balanced his right to refuse treatment against four potential state interests: preserving life, protecting innocent third parties, protecting the integrity of the medical profession, and preventing suicide. ${ }^{38}$ The court found that these interests did not outweigh Barthing's right to refuse treatment. ${ }^{39}$

\section{Barber v. Superior Court}

The Bouvia court also relied on the recent California case of Barber v. Superior Court. ${ }^{40}$ Barber involved an elderly man who had suffered brain damage and was in a permanent vegetative state. ${ }^{41}$ The patient's family sought the removal of lifesaving equipment, and his doctors comphied, removing a respirator and feeding tubes. The patient died. ${ }^{\mathbf{4 2}}$

The doctors were charged with inurder and conspiracy to commit inurder. ${ }^{43}$ They sought a writ of prohibition to restrain the trial court from proceeding on the criminal charges. ${ }^{44}$ The court of appeal held that the doctors were not hable for homicide because they had no duty to contimue providing ineffective medical treatment. ${ }^{45}$ The court reasoned that the withdrawal of "heroic" life-support ineasures is not an affirmative act but an omission of further treatment, and that doctors must respect a patient or surrogate decisionmaker's refusal of further life-sustaining treatment as an exercise of that patient's fundamental right to control her own medical care. ${ }^{46}$

Barber differs factually from cases like Bouvia and Bartling in that it imvolved an incompetent patient with hittle potential for physical recovery or cognitive life. Barber belongs to a distinct group of cases in which either an incompetent patient had previously requested that life-support measures be discontmued in such circumstances, or a family member independently decided that life-support should be withdrawn from an mcompetent patient. These cases does not give rise to the suicidal refusal

$\$ \S 7185-7195$ (West Supp. 1987), and in CAL. ADM1N. CodE tit. 22, § 70707(6) (1980). Bartling, 163 Cal. App. 3d at 194 \& n.5, 209 Cal. Rptr. at 224 \& n.5.

37. Bartling, 163 Cal. App. 3d at 193, 209 Cal. Rptr. at 223-24.

38. Id. at 193,209 Cal. Rptr. at 224.

39. Id. The court noted that one of these state interests-the protection of innocent third parties-was not implicated in the case. Id. at 195 n.6, 209 Cal. Rptr. at 225 n.6.

40. $147 \mathrm{Cal}$. App. 3d 1006, 195 Cal. Rptr. 484 (1983). See Bouvia v. Superior Court, 179 Cal. App. 3d 1127, 1137-38, 225 Cal. Rptr. 297, 301 (1986).

41. Barber, 147 Cal. App. 3d at 1010, 195 Cal. Rptr. at 486.

42. Id. at 1010-11, 195 Cal. Rptr. at 486.

43. Id. at 1010, $195 \mathrm{Cal}$. Rptr. at 486.

44. Id.

45. Id. at 1017, 1022, 195 Cal. Rptr. at 490-91, 493 .

46. Id. at 1015-16, 195 Cal. Rptr. at 489-90. 
problem because the patients involved do not directly request a course of action that will end their lives. Such cases are relevant to this Comment, however, because courts have decided them by first determining what the patient's rights to refuse treatment would be were she competent, and then addressing the special problems presented by the patient's incompetence. ${ }^{47}$

\section{In re Conroy, In re Quinlan, In re Welfare of Colyer}

This subsection groups together three recent, influential cases with facts similar to those of Barber. Despite their factual dissimilarities from Bouvia, these are the leading cases on the problem of suicidal refusals.

In re Conroy ${ }^{48}$ is a 1985 case in which the New Jersey Supreme Court produced a thoughtful and comprehensive opinion. Conroy involved an elderly woinan with permanent, severe inental and physical inpairments whose nephew sought to have life-sustaining treatment withdrawn. ${ }^{49}$ The Conroy court expanded on the reasoning of Bartling, finding support for the patient's right to refuse treatinent in informed consent doctrine, ${ }^{50}$ in the broader common law right of self-determination, ${ }^{51}$ and in the constitutional right of privacy, ${ }^{52}$ all of which are grounded in the "basic societal concept" of the right of a person to control her own body. ${ }^{53}$ The court reasoned that these rights, if they are to be meaningful, must protect a decision that goes against sound medical advice, even one that leads to the patient's death. ${ }^{54}$ The court considered the same four state interests considered by the Bartling court and determined that "the right to self-determination ordinarily outweighs any countervailing state interests, and [that] competent persons generally are permitted to refuse inedical treatinent, even at the risk of death."55

In Conroy, the New Jersey Supreine Court reaffirmed and broadened its landmark decision in In re Quinlan, ${ }^{56}$ which it had decided nine years earlier. Karen Quinlan, a twenty-two-year-old woinan, was in a permanent vegetative state. ${ }^{57}$ She was kept ahve by a respirator and feeding tube. $^{58}$ The supreine court ordered the appointinent of Quinlan's father as her guardian, with authority to have life-sustaining treatinent with-

47. See, e.g., id. at 1015-20, 195 Cal. Rptr. at 489-92.

48. 98 N.J. 321, 486 A.2d 1209 (1985).

49. Id. at $335-36,486$ A.2d at 1216 .

50. Id. at $346,486 \mathrm{~A} .2 \mathrm{~d}$ at 1222 .

51. Id. at 348,486 A.2d at 1223 .

52. Id.

53. Id. at $346,486 \mathrm{~A} .2 \mathrm{~d}$ at 1221 .

54. Id. at $352-53,486 \mathrm{~A} .2 \mathrm{~d}$ at 1225 .

55. Id. at 348-53, $486 \mathrm{~A} .2 \mathrm{~d}$ at 1223-25.

56. 70 N.J. 10, 355 A.2d 647 (1976).

57. Id. at $18,24-25,355 \mathrm{~A} .2 \mathrm{~d}$ at $651,654-55$.

58. Id. at $25,355 \mathrm{~A} .2 \mathrm{~d}$ at 655 . 
drawn if Quinlan's doctors and a hospital ethics committee concluded that there was no reasonable possibility of her returning to a cognitive, sapient state. ${ }^{59}$ The Quinlan court focused on constitutional privacy analysis. ${ }^{60}$ It found that Quinlan's rights outweighed the state interests in compelling treatment, but carefully limited its reasoning to the extreme facts of her case. ${ }^{61}$

The Conroy court also cited a recent Washington case that involved similar facts, In re Welfare of Colyer. ${ }^{62}$ In Colyer, the Washington Supreme Court found that the right of privacy extends to protect the "freedom to care for one's health and person," and is broad enough to encompass a right to refuse lifesaving treatment under certain circumstances. $^{63}$ The court considered the common law right to freedom from bodily mvasion as an alternative basis for the right to refuse treatment. ${ }^{64}$ For the informed consent doctrine to establish a meaningful freedom of choice, the court said, it must protect the patient's right to choose from among alternative forms of treatment or no treatment at all. ${ }^{65}$ The court found that while the state's interest in preserving life lias sometimes prevailed over this freedom of choice, the state's interest decreases in cases where contmued treatment serves only to prolong a life afflicted with an incurable condition. ${ }^{6}$

\section{Brophy v. New England Sinai Hospital}

A 1986 Massachusetts decision deserves special mention because the focal disagreement between the inajority and the dissenters turned on whether the refusal of treatment at issue constituted suicide. Brophy $v$. New England Sinai Hospital ${ }^{67}$ concerned an mcompetent, nonterminal patient in a persistent vegetative state. ${ }^{68}$ His wife and family sought to have his feeding tubes removed. ${ }^{69}$ Employing the doctrine of substituted judgment, ${ }^{70}$ the court found that since the patient would have refused

59. Id. at 55,355 A.2d at $671-72$.

60. Id. at 38,355 A.2d at 662 .

61. Id. at 38-39, 355 A.2d at 662-33 (emphasizing that Quinlan was "probably irreversibly doomed to no more than a biologically vegetative remnant of life" and distinguishing the "diametrically opposite case" where a patient is "salvable to long life and vibrant health").

62. 99 Wash. 2d 114, 660 P.2d 738 (1983).

63. Id. at $119-20,660$ P.2d at 742 .

64. Id. at 121-22, 660 P.2d at 743 .

65. Id. Like the Barber court, the court in Colyer found legislative recognition of these rights in the enactment of a Natural Death Act, WASH. Rev. Code ANN. $\$ 70.122$ (Supp. 1987). See Colyer, 99 Wash. 2d at 118-19, 660 P.2d at 741.

66. Colyer, 99 Wash. $2 \mathrm{~d}$ at $122-23,660$ P.2d at 743.

67. 398 Mass. 417,497 N.E.2d 626 (1986).

68. Id. at 419,497 N.E.2d at 627.

69. Id.

70. The doctrine of substituted judgment requires a court to appoint a surrogate decisionmaker who has the duty to try to make the same treatment decisions that the patient would if he were 
treatment in these circumstances, ${ }^{71}$ his wife's request was an exercise of his rights of common law bodily integrity and constitutional privacy. ${ }^{72}$ The court then considered the state interests articulated in Bartling ${ }^{73}$ and concluded that none was compelling. ${ }^{74}$ Three judges dissented, objecting that the court was granting the patient the right to kill himself. ${ }^{75}$ Brophy died eight days after his doctors removed the feeding tubes. ${ }^{76}$

\section{Other Authority}

Recent cases from other states are also in accord with the Bouvia and Bartling decisions. These cases are treated here collectively because they are less recent, less thoroughly reasoned, or less frequently cited than the cases discussed above.

The case most analogous to Bouvia is Satz v. Perlmutter. ${ }^{77}$ In Satz, a coinpetent, seventy-three-year-old patient who was paralyzed and terminally ill asked his doctors to remove his respirator. ${ }^{78}$ The Florida District Court of Appeal upheld his request, reasoning that the constitutional right of privacy protects the sanctity of individual choice and self-determination, including a competent patient's decision to refuse lifesaving treatment. ${ }^{79}$ The Satz court considered the same four state interests later discussed by the Bartling court, ${ }^{80}$ and found that they were outweighed by the patient's interests. ${ }^{81}$

Other state courts have used similar reasoning to uphold the right of elderly patients whose competence is in doubt to refuse potentially lifesaving operations. ${ }^{82}$ These decisions are interesting mainly for their

competent, based on the patient's prior medical decisions and religious and philosophical convictions. See id. at 427-29, 497 N.E.2d at 631-32; In re Conroy, 98 N.J. 321, 357-65, 486 A.2d 1209, 1227-32 (1985).

71. The record included evidence of numerous remarks by the patient, both before and after he learned of his illness, that he would not want to be kept alive in a vegetative state. Brophy, 398 Mass. at 428,497 N.E.2d at $631-32$.

72. See id. at $429-32,497$ N.E.2d at $632-34$.

73. Namely, preserving life, protecting third parties, protecting the integrity of the medical profession, and preventing suicide. See supra text accompanying note 38 .

74. Brophy, 398 Mass. at $432-40,497$ N.E.2d at 634-38. The Brophy court cited Bouvia with approval. See id. at $432,435-36,497$ N.E.2d at 634, 636-38.

75. Id. at $446-48,497$ N.E.2d at 642-43 (Lynch, J., dissenting in part); id. at 448-50, 497 N.E.2d at 643-44 (O'Connor, J., concurring in part and dissenting in part). For a discussion of these opinions, see infra notes $217-20$ and accoinpanying text.

76. Brophy Dies 8 Days After Feedings are Halted, Boston Globe, Oct. 24, 1986, § 1, at 1, col. 2.

77. 362 So. 2d 160 (Fla. Dist. Ct. App. 1978), aff'd, 379 So. 2d 359 (Fla. 1980).

78. Id. at 161 (The patient was quoted as saying, "I'm iniserable ... [death] can't be worse than what I'm going through now").

79. See id. at 162 .

80. See supra note 73 ; supra text accoinpanying note 38 .

81. Satz, 362 So. $2 \mathrm{~d}$ at $162-64$.

82. Lane v. Candura, 6 Mass. App. Ct. 377, 376 N.E.2d 1232 (1978) (77-year-old woman with severe gangrene had right to refuse lifesaving operation, based on constitutional right to privacy and 
struggles with the troublesome issue of competence. One of them, Lane v. Candura, ${ }^{83}$ is discussed in that context in Part III below. ${ }^{84}$

In three other cases, In re Lydia E. Hall Hospital, ${ }^{85}$ In re Storar, ${ }^{86}$ and Superintendent of Belchertown State School v. Saikewicz, ${ }^{87}$ state courts also upheld the right of patients to refuse treatment. Lydia and Storar relied solely on the cominon law right of self-determination. ${ }^{88}$ Saikewicz relied additionally on constitutional privacy analysis. ${ }^{89}$ All three cases balanced the patient's rights against countervailing state interests and concluded that the patient's riglits should prevail. ${ }^{90}$

\section{The Religious Refusal Cases}

Finally, there is a group of older cases in which patients refused specific treatinents on religious grounds. ${ }^{91}$ The patients in these cases were generally young and healtlyy aside from an acute, remediable condition, and did not object to the pain or disability accompanying treatment, nor to the artificial prolongation of life. Instead, their religious beliefs

right of self-determination); In re Quackenbush 156 N.J. Super. 282, 383 A.2d 785 (1978) (72-yearold patient adjudged competent to refuse amputation of his legs for gangrene, although his reasons for refusal appeared irrational, based on constitutional privacy and informed consent doctrine); In re Yetter, 62 Pa. D. \& C.2d 619 (Northhampton County Ct. 1973) (mentally ill but competent patient could refuse breast biopsy, although her refusal was sometimes accompanied by delusions).

83. 6 Mass. App. Ct. 377, 376 N.E.2d 1232 (1978).

84. See infra text accompanying notes 146-51.

85. 116 Misc. 2d 477, 455 N.Y.S.2d 706 (Sup. Ct. 1982). The 41-year-old patient, suffering from multiple, grave illnesses, had refused dialysis while competent, before lapsing into a coma. Id. at $480-84,455$ N.Y.S.2d at $709-10$. The court held that his previous refusal had to be respected. Id. at 488,455 N.Y.S.2d at 713.

86. 52 N.Y.2d 363, 420 N.E.2d 64, 438 N.Y.S.2d 266 (deciding two cases), cert. denied, 454 U.S. 858 (1981). The court held that: (1) a respirator could be withdrawn from an elderly comatose patient who had publicly expressed a desire not to be kept alive by heroic measures, id. at 369-72, 420 N.E.2d at $67-68,438$ N.Y.S.2d at $269-70$; and (2) transfusions for a terminally ill, severely retarded cancer patient should be continued, because they enabled lim to continue to function at his usual mental and physical quality of life, id. at 380-82, 420 N.E.2d at 72-74, 438 N.Y.S.2d at 274-76.

87. 373 Mass. 728,370 N.E.2d 417 (1977) (painful treatment could be withheld from severely retarded patient dying of leukemia).

88. Lydia, 116 Misc. 2d at 485-87, 455 N.Y.S.2d at 711-12; Storar, 52 N.Y.2d at 376, 420 N.E.2d at 70,438 N.Y.S.2d at $272-73$. The Storar court commented that, because the Supreme Court has declined to address the question, it was unclear whether a constitutionally protected right to refuse treatment exists. Id.

89. Saikewicz, 373 Mass. at 738-39, 370 N.E.2d at 424.

90. Saikewicz, 373 Mass. at 759, 370 N.E.2d at 435 ; Storar, 52 N.Y.2d at 377,420 N.E.2d at 71,438 N.Y.S.2d at 273 (patient prevailed in one of two jointly decided cases); Lydia, 116 Misc. 2d at $486-87,455$ N.Y.S.2d at 711-12.

91. See, e.g., In re President and Directors of Georgetown College, 331 F.2d 1000 (D.C. Cir.), cert. denied, 377 U.S. 978 (1964); United States v. George, 239 F. Supp. 752 (D. Conn. 1965); In re Osborne, 294 A.2d 372 (D.C. 1972); In re Estate of Brooks, 32 Ill. 2d 361, 205 N.E.2d 435 (1965); Hamilton v. McAuliffe, 277 Md. 336, 353 A.2d 634 (1976); John F. Kennedy Memorial Hosp. v. Heston, 58 N.J. 576, 279 A.2d 670 (1971); Powell v. Columbian Presbyterian Medical Center, 49 Misc. 2d 215, 267 N.Y.S.2d 450 (Sup. Ct. 1965). 
forbade them to consent to particular kinds of treatment. ${ }^{92}$ Some of these cases were further complicated because the patients appeared only to want to avoid giving consent to the treatment, not to avoid the treatment itself. $^{93}$ Many of these opinions are not thoroughly reasoned because the cases involved einergency situations in which a judge made a hurried ruling and the losing party took an equally hurried appeal. ${ }^{94}$ The involveinent of first ainendinent riglits concerning the free exercise of religion further complicated some of these cases. ${ }^{95}$

Notwitlistanding these distinguishing factors, the religious refusal cases develop two ideas that are particularly relevant to the probleins presented by Bouvia. The first is that the protection of the right to refuse treatınent is not restricted to reasonable decisions:

Even though we may consider appellant's beliefs unwise, foolish or ridiculous, in the absence of an overriding danger to society we may not permit interference therewith .... In the final analysis, what has happened here involves a judicial attempt [by the trial court] to decide what course of action is best for a particular individual, notwithstanding that individual's contrary views based upon rehigious convictions. Such action cannot be constitutionally countenanced. ${ }^{96}$

Second, there is a related idea that inoral outrage caused by a patient's refusal of treatınent on religious grounds is never a sufficiently compelling public interest to override the patient's choice:

[F]reedom to differ is not himited to things that do not matter much.

That would be a mere shadow of freedom. The test of its substance is the right to differ as to things that touch the heart of the existing order. ${ }^{97}$

Like the rights of privacy and self-determination invoked in the nonreligious refusal cases, these two ideas froin the religious refusal cases imply that the right to refuse treatment should not be restricted by a standard of reasonableness or public acceptability. ${ }^{98}$ The retigious

92. For example, Jehovah's Witnesses will not accept blood transfusions because the Bible forbids the drinking of blood. Acts of the Apostles 15:29; see generally WATCHTOWER BIBLE AND TRACT SOC'Y OF New YoRK, INC., BloOd MEdicine AND THE LAW OF GOD (1961).

93. In Georgetown, George, and Powell, the patients all indicated that they wished to live, but would rather die than consent to a transfusion; they also implied that the transfusion would not be on their consciences if it was ordered by the court. Georgetown, 331 F.2d at 1007; George, 239 F. Supp. at 753; Powell, 49 Misc. 2d at 215-16, 267 N.Y.S.2d at 451.

94. See, for example, Judge Wright's account of his sudden and dramatic involvement in the case of a Jehovah's Witness who refused an emergency blood transfusion, Georgetown, 331 F.2d at 1006-07, and the similar sense of urgency expressed by the court in Powell, 49 Misc. 2d at 216, 267 N.Y.S.2d at 451-52. Transfusions were ordered over the patients' objections in both cases.

95. See, e.g., Brooks, 32 Ill. $2 \mathrm{~d}$ at 366-67, 205 N.E.2d at 438-39.

96. Id. at 373,205 N.E.2d at 442.

97. Id. at 371, 205 N.E.2d at 441 (quoting West Va. State Bd. of Educ. v. Barnette, 319 U.S. 624,642 (1942)).

98. Courts should be careful to distinguish between the reasonableness or rationality of the particular decision and the competence of the decisionmaker. See infra text accompanying notes 141-52. 
refusal cases make this point particularly clearly because of the obvious danger of challenging rehigious behefs and the conduct they recommend on the grounds that they are unreasonable or socially offensive. These cases also highlight the difference between a patient's insistence on making decisions contrary to orthodox medical and inoral judgment and a patient's incompetence to make decisions about her own treatment.

\section{The Uncertainty of Present Doctrine}

The refusal of treatment cases leave several important questions open. The theoretical scope of the right to refuse treatment is much broader than the range of factual situations in which that right has so far been asserted. With the exception of Elizabeth Bouvia, all the patients in these cases, even those not considered terminally ill, were near death. None was expected to hive inuch more than a year, even with treatment. Many of the decisions expressly limited their holdings to patients in such positions. ${ }^{99}$ But more recent decisions have presented the right to refuse treatment as if it applied equally to all patients, curable or not. ${ }^{100}$ Indeed, the Bouvia and Bartling courts stated that there is no principled reason to limit the right to refuse treatment to patients who are terminally ill. ${ }^{101}$

Further, most of the refusal cases have involved elaborate, invasive

99. The Brophy court distinguished the case of an incurable patient from one in which the patient is curable and a decision to refuse treatment would be "aberrational," suggesting that, in the latter situation, the patient's right to refuse would be outweighed by the state's interest in preserving life. Brophy v. New England Sinai Hosp., 398 Mass. 417, 433-34 \& n.28, 497 N.E.2d 626, 635 \& n.28 (1986). The Colyer court characterized its holding as recognizing the right of a terminally ill patient to refuse treatment that only prolongs the dying process. In re Colyer, 99 Wash. 2d 114, 120, 660 P.2d 738, 742 (1983). In Satz and Saikewicz, the courts went further, explicitly distinguishing cases where the patient's affiction is curable, from cases where "the issue is not whether, but when, for how long, and at what cost to the individual that life can be briefly extended." Satz v. Perlmutter, 362 So. 2d 160, 162 (Fla. Dist. Ct. App. 1978) (quoting Superintendent of Belchertown State School v. Saikewicz, 373 Mass. 728, 741-42, 370 N.E.2d 417, 425-426 (1977)). The court in In re Quinlan, 70 N.J. 10, 355 A.2d 647 (1976), drew a similar distinction. See supra note 61.

100. The Conroy court stated that the right to accept or refuse inedical treatment does not depend on the patient's prognosis or medical condition, or on the quality or value of her life. In re Conroy, 98 N.J. 321, 355, 486 A.2d 1209, 1226 (1986). In Conroy, the court's point was that patients should not be deprived of the right because their debilitated condition renders thein unable to make decisions. But the argument cuts both ways: Patients should also not be deprived of the right to refuse treatment because they are "not debilitated enough."

101. Bouvia v. Superior Court, 179 Cal. App. 3d 1127, 1139, 225 Cal. Rptr. 297, 302 (1986) ("[T]here is no practical or logical reason to limit the exercise of this right to "terminal' patients."); Bartling v. Superior Court, 163 Cal. App. 3d 186, 193, 209 Cal. Rptr. 220, 223 (1984) (trial court was incorrect in limiting the right to refuse to terminal patients). The Bouvia court continued:

All decisions permitting cessation of medical treatment or life-support procedures to some degree hastened the arrival of dcath. . . . If [Bouvia's] right to choose may not be exercised because there remains to her, in the opinion of a court, a physician or some cominittee, a certain arbitrary number of years, months, or days, her right will have lost its value and meaning.

Bouvia, 174 Cal. App. 3d at 1142-43, 225 Cal. Rptr. at 304. 
treatments, such as artificial respirators, dialysis, or amputation. Although soine cases have suggested that a patient's rights increase with the degree of intrusiveness of the proposed treatment, ${ }^{102}$ several recent cases, mclnding Bouvia, have declined to limit the right to refuse on the basis of the nature of the treatment. ${ }^{103}$ Hence, it is often unclear whether the courts' holdings would differ if the refused treatment had been minimally intrusive, such as an oral medication with minimal side effects. ${ }^{104}$ Brophy is of particular interest in this connection because, as the dissenters pointed out, the court's reasoning appears to hicense patients to refuse even minimally imvasive treatment. ${ }^{105}$ The Brophy court's inquiry focused on the patient's actual or surrogate choice, not on distinctions among types of treatment or degrees of bodily invasion. The dissenters objected to this expansion of the right to refuse treatment, one argumg that the expansion implies at least a limited "right to die,"106 the other that it is prennised on a right to commit suicide. ${ }^{107}$

Thus, at this point in the development of the doctrine, it is unclear whether the right to refuse treatment can justifiably be confined to patients near death who resist highly mvasive treatments, or whether its logic compels recognition of a broad right to die by refusing treatinent.

Bouvia's case was umque because of her youth, intelligence, and potential for long life. Moreover, she was voluntarily resisting food and water, the basic necessities of life. Because no other cases involving these facts have been decided, it is not clear whether Bouvia represents an anomalous doctrinal extreme or the forefront of a developing legal trend.

102. The Quinlan court's statement that the patient's right to refuse "grows as the degree of bodily invasion increases and the prognosis dims," Quinlan, 70 N.J. at 41, 355 A.2d at 664, was cited in both In re Quackenbush, 156 N.J. Super. 282, 289, 383 A.2d 785, 789 (1978), and In re Welfare of Colyer, 99 Wash. 2d 114, 122, 660 P.2d 738, 743 (1983).

103. Bouvia, $179 \mathrm{Cal}$. App. 3d at 1137, $225 \mathrm{Cal}$. Rptr. at 300 (flatly stating that the right to refuse extends to any and all medical treatment); Barber v. Superior Court, 147 Cal. App. 3d 1006, 1016, 195 Cal. Rptr. 484, 490 (1980) (rejecting distinction between feeding tubes and other treatments); Conroy, 98 N.J. at 370-74, 486 A.2d at 1234-37 (rejecting proposed distinction between feeding tubes and other treatments, and, more generally, between ordinary and extraordinary means of treatment); Quinlan, 70 N.J. at 48, 355 A.2d at 667-68 (rejecting distinction between ordinary and extraordinary treatment); see also Bartling, 163 Cal. App. 3d at 193-94, 209 Cal. Rptr. at 224 (articulating without qualification a right to determine whether or not to submit to medical treatment, but noting that that ease involved highly invasive trcatment).

104. For example, the Quinlan court both rejected the distinction between ordinary and extraordinary treatment and asserted that the right to refuse increases with the degree of intrusiveness of the proposed treatment. Compare Quinlan, 70 N.J. at 48, 355 A.2d at 667-68 with id. at $41,355 \mathrm{~A} .2 \mathrm{~d}$ at 664 .

105. Brophy, 398 Mass. at 445,497 N.E.2d at 641 (Lynch, J., dissenting in part); id. at 449,497 N.E.2d at 643 (O'Connor, J., concurring in part and dissenting in part).

106. Id. at 445,497 N.E.2d at $641-42$ (Lynch, J., dissenting in part).

107. Id. at 452,497 N.E.2d at 645 (O'Connor, J., concurring in part and dissenting in part). 
II

\section{The Basis of The Right to Refuse TREatment}

The scope of the right to refuse treatment is not precisely defined because courts have considered that right only in a limited range of fact situations and have based it, without detailed analysis, on broader rights, such as the common law right of self-determination and the constitutional right of privacy. Courts have not articulated which of several distinct interests they intend to protect. This lack of clarity is significant because the extent of the right to refuse treatment varies depending upon which of the various underlying mterests that right is expected to protect.

\section{A. Common Law Interests in Bodily Integrity}

The right to refuse treatment exemplifies the right of a person to control her own body, a right with ancient roots in the common law. ${ }^{108}$ It is well articulated by two often-quoted judicial statements. In 1891, the Umited States Supreme Court observed:

No right is held more sacred, or is more carefully guarded by the common law, than the right of every individual to the possession and control of his own person, free from all restraint or interference of others, unless by clear and unquestionable authority of law. As well said by Judge Cooley, "The right to one's person may be said to be a right of complete immunity: to be let alone." 109

And in 1914, the New York Court of Appeals stated succinctly that "Every human being of adult years and sound mind has a right to determime what shall be done with his own body." 110

The right to refuse treatment derives from informed consent, the common law doctrine in which the right of bodily integrity has been most clearly articulated. ${ }^{111}$ This doctrine defines the doctor's duties to disclose to the patient the risks and benefits of a proposed course of treatment and its alternatives, and to proceed only if the patient understands and consents to the treatment. If a doctor treats a patient without informed consent, the doctor is liable for battery, regardless of whether

108. See Conroy, 98 N.J. at 346, 486 A.2d at 1221 (calling the right a "basic societal concept, long recognized in the common law"); Cantor, A Patient's Decision to Decline Life-Saving Medical Treatment: Bodily Integrity Versus the Preservation of Life, 26 RuTGERS L. REV. 228, 236 (1973) ("The 'right' of an individual to determine when bodily invasions will occur is by no means a novel jurisprudential concept. Bodily integrity has often been recognized by the judiciary as an important value and has enjoyed protection under both the common law and the Constitution.").

109. Union Pac. Ry. v. Botsford, 141 U.S. 250, 251 (1891) (quoting T. Cooley, A Treatise ON THE LAW OF TORTS 29 (1888)).

110. Schloendorff v. Society of New York Hosp., 211 N.Y. 125, 129-30, 105 N.E. 92, 93 (1914).

111. Shultz, From Informed Consent to Patient Choice: A New Protected Interest, 95 YALE L.J. 219, 224-27 (1985). 
the treatment benefits the patient. ${ }^{112}$

Recent commentators on the informed consent doctrine have argued that its logic requires courts to give patient autonomy a broader scope than they generally have, ${ }^{113}$ and that courts should limit the traditional deference to medical authority to "do what is best for the patient."114 These commentators have expanded the doctrine from its historical focus on the prohibition of unconsented touching of the patient's body to encompass the broader rights of decisional autonomy and selfdetermination. $^{115}$

A broad view of informed consent was endorsed by the Califormia Supreme Court in Cobbs v. Grant, ${ }^{116}$ which was relied on as a leading California case by the Bouvia court. ${ }^{117}$ The Cobbs court reasoned that a doctor's expertise and authority extend only to advising the patient and disclosing significant risks and benefits of treatment alternatives. ${ }^{118}$ Once the patient has received and understood this information, the final treatinent decision based on her weigling of the risks against ler personal fears and lopes is a nonmedical judgment reserved to her alone. ${ }^{119}$

The right of bodily self-determination as expressed in the informed consent doctrine can be interpreted as protecting two interests: the interest in being free from nonconsensual bodily invasion and the interest in decisioimiaking autono1ny. The first interest concerns the limits of inedical and institutional control over the patient's body; the second, the

112. Id. at 224; Schloendorff, 211 N.Y. at 129-30, 105 N.E. at 93; Cantor, supra note 108, at 237.

113. See, e.g., Shultz, supra note 111 (arguing that courts should consider patient autonomy a legally protected interest independent of the informed consent and professional competence doctrines' traditional protections of patients' bodily security and well-being).

114. See Meisel, The "Exceptions" to the Informed Consent Doctrine: Striking a Balance Between Competing Values in Medical Decisionmaking, 1979 WIS. L. REV. 413. After reviewing the emergency, incompetence, waiver, and therapeutic privilege exceptions to the informed consent doctrine, Meisel concludes:

There is a single thread connecting all of the exceptions, and that thread is made up of the values that I have referred to as "health" values-the health of the individual for the individual's own sake, the maintenance and promotion of the health of loved ones, and the assurance that the medical and related professions are free to practice responsibly in accordance with sound professional dictates.

Id. at 487.

115. Shultz concludes that "medical decisions depend upon moral values, economic considerations and risk preferences, as well as on medical expertise. Because health care decisions affect the patient more directly than anyone else, the patient's choices, educated but not preempted by the doctor's expertise, should be controlling." Shultz, supra note 111, at 299. Meisel says that courts should recognize that "there must be some external force for bringing individualistic values into play" in medical decisionmaking. Meisel, supra note 114, at 488 .

116. 8 Cal. 3d 229, 502 P.2d 1, 104 Cal. Rptr. 505 (1972).

117. See Bouvia v. Superior Court, 179 Cal. App. 3d 1127, 1137, 225 Cal. Rptr. 297, 300 (1986).

118. Cobbs, 8 Cal. 3d at 243-44, 502 P.2d at 10, 104 Cal. Rptr. at 514.

119. Id. 
extent of the patient's authority to make health care decisions imdependently.

\section{B. Constitutionally Protected Privacy Interests}

First recognized in cases involving reproductive choice, ${ }^{120}$ the constitutional right of privacy both echoes and augments the right of autonomous decisionmaking. Some refusal of treatment cases have treated the constitutional right of privacy and the common law right of self-determination as separate doctrinal paths to a common destination, ${ }^{121}$ while others have rehed exclusively on the privacy right. ${ }^{122}$ None of the cases, however, has determined how the nature or scope of the right to refuse treatment might vary according to whether it is based on privacy or on self-determination. Cases that have invoked the right of privacy have not provided much analysis beyond their conclusory statements that it extends far enough to encompass patients' refusals of treatment. ${ }^{123}$

The origin of the doctrine of privacy in the context of reproductive choice issues suggests two interests that inay be implicit in the refusal of treatınent cases. The first is the interest in decisional autonomy, ${ }^{124}$ which overlaps with the modern interpretation of the informed consent doctrime. The other is an interest in noninterference with personal free-

120. See, e.g., Roe v. Wade, 410 U.S. 113 (1973); Griswold v. Connecticut, 381 U.S. 479 (1965). These two bases for the right to refuse are, of course, not entirely distinct. The development of the privacy right drew on the common law right of self-determination, as can be seen from Justice Brandeis's dissenting opinion in Olmstead v. United States, 277 U.S. 438 (1928), often cited as a leading argument for the constitutional right of privacy: "The makers of our Constitution .... sought to protect Americans in their beliefs, their thoughts, their emotions and their sensations. They conferred, as against the Government, the right to be let alone-the most comprehensive of rights and the right most valued by civilized men." Id. at 478 (Brandeis, J., dissenting).

121. See, e.g., Bouvia, 179 Cal. App. 3d at 1137-38, 225 Cal. Rptr. at 301 (discussing both constitutional privacy and informed consent as bases of right to refuse treatment); Superintendent of Belchertown State School v. Saikewicz, 373 Mass. 728, 739, 370 N.E.2d 417, 424 (1977) (basing right to refuse trcatment on both privacy and the common law "interest in being free from nonconsensual invasion of . . bodily integrity"); In re Conroy, 98 N.J. 321, 348, 486 A.2d 1209, 1223 (1985) (immaterial to court's analysis whether right to refuse treatment is "based on commonlaw doctrines or on constitutional theory"); In re Colyer, 99 Wash. 2d 114, 120-21, 660 P.2d 738, 742-43 (1983) (finding privacy and common-law self-determination to be alternate bases for right to refuse treatment).

122. See, e.g., Bartling v. Superior Court, 163 Cal. App. 3d 186, 195, 209 Cal. Rptr. 220, 225 (1984) (patients' right to refuse treatment "has its origins in the constitutional right of privacy"); Satz v. Perlmutter, 362 So. 2d 160, 162 (Fla. Dist. Ct. App. 1978) (right to refuse based solely on privacy).

123. See, e.g., In re Quinlan, 70 N.J. 10, 40, 355 A.2d 647, 663 (1976); Colyer, 99 Wash. 2d at 120,660 P.2d at 742 . These cases appear to rely on a broad, all-inclusive view of the constitutional right to privacy that makes detailed analysis and argument unnecessary. Cantor predicts that a broad interpretation of privacy will become central to refusal of treatment cases: "My thesis is that this broader right of privacy will be viewed as a fundamental aspect of personal liberty, a prerequisite or predicate to the exercise of all other liberties." Cantor, supra note 108, at 241.

124. Thus Roe emphasizes the detriment to a pregnant woman's freedom of choice from interference with her decision whether to have an abortion. Roe, 410 U.S. at 153. 
dom in especially intimate "zones of privacy," such as marital sexual activity and family planning. ${ }^{125}$ Some of the language in refusal of treatment cases suggests that death and dying might occupy one of these zones. One example is the statement in Conroy that patients are increasingly asserting a right to die a natural death without unwanted interference by medical technology - a right to "die with dignity."126 Judge Compton, concurring in Bouvia, used even stronger language, arguimg that "[t]he right to die is an integral part of our right to control our own destinies so long as the rights of others are not affected,"127 and that "[i]f there is ever a time when we ought to be able to get the 'government off our backs' it is when we face death-either by choice or otherwise."128

\section{The Need for Clarification}

These three versions of the patient's protected interest-as an interest in being free from bodily mvasion, as an interest im preserving one's decisional autonomy, and as an imterest in maintaining one's privacy within an intimate zone--are closely related but not identical. Each suggests different limitations on the right to refuse treatment.

For example, the interest $\mathrm{m}$ being free from bodily invasion becomes stronger as the proposed treatment becomes more imvasive. Although compelling one patient to undergo dialysis and compelling another to take a simple oral medication might equally violate each patient's decisional autonoiny and equally intrude into intimate areas of each patient's life, the dialysis patient might have a stronger right to refuse treatment because of the greater bodily invasion involved. Likewise, the concept of a zone of privacy surrounding death and dying suggests that a terminally ill patient has a stronger right to refuse treatment than has a curable patient, even if the magnitude of bodily invasion and the violation of autonomy were the same for both.

The disparate levels of interest that courts in refusal of treatinent cases have shown concerning the relative invasiveness of various treatments and the relative proximity to death of various patients inay well

125. This theme predominates in Griswold, in which the Court, in invalidating a state ban on the sale of contraceptives, emphasized the sanctity of the home and "marital bedrooms" as domains of individual freedom. Griswold, 381 U.S. 479, 484-86 (1965).

126. Conroy, 98 N.J. at 343, 486 A.2d at 1220; see also In re Yetter, $62 \mathrm{~Pa}$. D. \& C.2d 619, 623 (Northhampton County Ct. 1973) ("[I]n short, . . . the right of privacy includes a right to die with which the State should not interfere where there are no minor or unborn children and no clear and present danger to public health, welfare or morals.").

127. 179 Cal. App. 3d at 1147, 225 Cal. Rptr. at 307 (Compton, J., concurring).

128. Id. at 1148, $225 \mathrm{Cal}$. Rptr. at 308. Note, however, that at least so far, the Supreme Court has been reluctant to expand the scope of interests protected by constitutional privacy beyond matters of family, marriage, or procreation. See Bowers v. Hardwick, 106 S. Ct. 2841, 2844 (1986). 
reflect different judicial choices as to the interest or interests on which the right to refuse treatment should be based.

To clarify just how the right to refuse treatment will apply in future cases, courts must differentiate among these interests, moving froin broad references to privacy and self-determination toward a more precise articulation of the nature and interrelation of the various interests that right protects. All three interests embody values that may be implicit in the courts' apparent reluctance to treat a patient's refusal of treatment as suicide, and these must be weighed against the state interest in preventing suicide.

\section{III}

\section{The Problematic Requirement of Patient COMPETENCE}

When a patient's decision to refuse treatment is challenged, courts logically will first determine whether the patient is coinpetent to refuse. ${ }^{129}$ An incoinpetent patient, by definition, lacks decisionmaking ability. Hence, her resistance to treatnient does not amount to an invocation of the right to refuse treatment, and the task of weighing the patient's rights against the relevant state interests never arises. ${ }^{130}$

The distinction between competent and incompetent patients is made at two different levels. First, there is a threshold inquiry whether the patient is coinpetent in the sense of being conscious and capable of expressing her desires concerning treatment. If the patient is unable to express her desires, the court must determine who has authority to inake treatment decisions for her, and what decisions may be made. Second, for those patients capable of expressing their desires there is a further inquiry concerning coinpetence: should the patient's desires be taken seriously or, alternatively, should they be regarded not as true expressions of the patient's will but as the niere results of mental or physical illness, senility, or the side effects of medication. This Comment is concerned with the second competence question, which arises when patients express arguably irrational desires.

Although coinpetence was a central issue in several of the refusal of treatinent cases discussed in Part I, no court has articulated a test of

129. Patients' refusals have apparently more often been overridden because they were found incompetent than because of compelling state interests. The Conroy court commented that most cases in which patients' refusals were overruled "concerned the patient's competency to makc a rational and considered choice of treatment," and stressed the difficulty of assessing the paticnt's competency and true desires in an emergency situation. Conroy, 98 N.J. at 353-54, 486 A.2d at 1225 26.

130. Of course, such a patient's right to refuse treatment could still be exercised by a surrogate decisionmaker, as in Conroy and Brophy. This Comment considers only the casc of a patient who herself resists treatment. 
competence specifically designed for the refusal of treatment situation. Instead, the courts appear to have accepted without discussion the general test of competence for informed consent: whether the patient is suffciently able to comprehend his situation, the alternatives available, and the risks and possible benefits of each alternative, so as to make an informed decision. ${ }^{131}$ Courts have declined to face squarely special problems concerning competence to refuse life-sustaining treatment. The courts' failure to define competence exphicitly in this context and to look beyond the facts of the particular case at bar makes the questions raised by Bouvia even harder to resolve.

Moreover, some courts have failed to recognize the important possibilities for abuse that inhere in the competence mquiry. First, doctors and hospital staff who oppose a patient's decision might manipulate the competence threshold. To get around a patient's refusal of treatment, doctors can wait until the patient becomes incompetent and then initiate a guardianship proceeding to compel treatment. For example, im one religious refusal case, Holmes v. Silver Cross Hospital, ${ }^{132}$ the planitiff alleged that her husband's doctors had violated his rights "through a scheme whereby [they] . . . waited until he had lost consciousness and then proceeded to obtain ... a decree of incompetency."133

Some courts have overlooked the unfairness of this type of maneuver. One court supported its decision to compel treatment by stating that the patient was near death and not in her right mind at the time of the litigation, ignoring the fact that the patient had made her refusal of treatment clear to her doctors long before her condition became critical. ${ }^{134}$

Because a refusing patient's judgment is likely to deteriorate rapidly, the court should consider the patient's competence at the time of the refusal, not at the time when that refusal is later challenged. ${ }^{135}$ One commentator argues that a patient who refuses lifesaving treatment

will inevitably become confused or debilitated and unable to exercise rational judgment. Physicians and hospital staff must, in good con-

131. This test was derived from the traditional test for capacity to contract: whether the person making an agreement could understand its nature, terms, and effect. In re Schiller, 148 N.J. Super. 168, 180-81, 372 A.2d 360, 367 (Ch. Div. 1977) (test of capacity to consent to treatment is: "Does the patient have sufficient mind to reasonably understand the condition, the nature and effect of the proposed trcatment, attendant risks in pursuing the treatment, and not pursuing the treatment?'); Grannum v. Berard, 70 Wash. 2d 304, 307, 422 P.2d 812, 814 (1967); Note, Informed Consent and the Dying Patient, 83 YALE L.J. 1632, 1653 (1974).

132. 340 F. Supp. 125 (N.D. Ill. 1972).

133. Id. at 136.

134. See In re President and Directors of Georgetown College, 331 F.2d 1000, 1008 (D.C. Cir.), cert. denied, 377 U.S. 978 (1964); see also Riga, Compulsory Medical Treatment of Adults, 22 CATH. LAw. 105, 124 (1976) ("The fact of the matter was that [the patient in Georgetown] refused medical treatment, and made known her refusal, long before she reached a critical state.").

135. See In re Yetter, 62 Pa. D. \& C.2d 619, 624 (Northhampton County Ct. 1973). 
science, resist the temptation to wait until the patient has lost competency before seeking judicial intervention. ... Once the patient has made a clear decision while competent, it must be respected unless altered. ${ }^{136}$

Second, competence has been challenged because the patient has vacillated between consent and refusal. Such challenges can be made when it is difficult to ascertam a patient's wishes or when those wishes are themselves ambiguous. For example, the patient in Bartling, who was found competent, had executed various formal documents expressing his desire that life support be withdrawn and stating his knowledge that this would cause death. ${ }^{137}$ But there was also testimony that he had made statements to his doctors and nurses suggesting that he wanted to live, and that on several occasions wlien the tubes of his respirator had been accidentally disconnected he had signalled frantically to have them replaced. ${ }^{138}$ Sucl ambivalent conduct raises a legitimate concern that the patient reach a settled decision that is clearly understood by medical staff before her treatment is ceased. This concern, however, does not justify denying a patient her right to refuse treatment on the ground that she vacillated before reaching the settled decision. ${ }^{139}$ Fluctuations in lucidity and resolve are likely to occur when a person is close to death and confronted with her family and doctors' opposition to her decision to die. But once the court is satisfied that the patient has come to an informed and definite decision, her past hesitation should not negate her right to refuse. ${ }^{140}$

The third and most important problem with competence determinations is that courts have sometimes confused the question of general decisionmaking ability witl the rationality of the particular decision at issue. For example, in State Department of Human Services v. Northern, ${ }^{141}$ the patient was "lucid and apparently of sound mind generally."142 But on the subjects of death and the amputation of her gangrenous feet, the court found that "her compreliension is blocked, blinded or dimmed to the extent that she is incapable of recognizing facts which would be obvious to a person of normal perception."143 The Northern court defined competence as the "mental ability to make a rational decision, which includes the ability to perceive, appreciate all relevant facts and to reach

136. Cantor, supra note 108 , at 251 n.117.

137. Bartling v. Superior Court, 163 Cal. App. 3d 186, 190-93, 209 Cal. Rptr. 220, 222-23 (1984).

138. Id. at 192, 209 Cal. Rptr. at 223.

139. The Bartling court concluded that the evidence of ambivalence did not justify his doctors' decision to disregard the patient's competent refusal. Id. at 193, 209 Cal. Rptr, at 223-24.

140. See Lane v. Candura, 6 Mass. App. Ct. 377, 384, 376 N.E.2d 1232, 1236 (1978).

141. 563 S.W.2d 197 (Tenn. Ct. App. 1978).

142. Id. at 209.

143. Id. at 209-10. 
a rational judgment upon such facts." 144 The court might have been justified in concluding that Northern was "partially incompetent," since she denied that anything was wrong with her obviously diseased feet and expressed the incompatible desires both to live and to forego amputation. ${ }^{145}$ The court's reasoning was flawed, however, because the appropriate inquiry is not whether the patient's specific, isolated decision to refuse treatment is "rational," but mstead whether the patient is generally able to make informed decisions about her medical care.

This more sensible view is illustrated in Lane v. Candura, ${ }^{146}$ which was factually similar to Northern. ${ }^{147}$ The Lane higation began when a Massachusetts trial court ordered treatment for a patient because it found that she had not inade her decision to refuse treatment based on "careful consideration of the medical alternatives" but had "closed her mind to the entire issue." 148 The Massachusetts Appeals Court reversed, reasoning that the presumption of the patient's competence could not be overcome even by evidence that the patient was elderly, that she had symptoins of depression and senility, that her decision mvolved strong einotional factors, and that she was unwilling to discuss it except with trusted family members. ${ }^{149}$ Further, that her decision was "irrational" did not mean that she was incompetent to make it, because the law protects the right to refuse treatment, wisely or not. ${ }^{150}$

Courts should follow Lane in guarding against the "grave danger that any decision by the patient that is mconsistent with the general mores of society could in fact be viewed by a court as evidence of incoinpetency." 151

Holmes, Bartling, Northern, and Lane suggest what courts should not do in future cases: allow medical staff to manipulate the determination of competence; treat patients' past imdecision like present imcompe-

144. Id. at 209.

145. Id. at 210 .

146. 6 Mass. App. Ct. 377,376 N.E.2d 1232 (1978).

147. The issue in both cases was whether an elderly patient was competent to decide whether to undergo an operation on a gangrenous limb. Id.

148. Lane, 6 Mass. App. Ct. at 379,376 N.E.2d at 1233-34.

149. Id. at 382,376 N.E.2d at 1235.

150. Id. at 383, 376 N.E.2d at 1235-36; accord In re Yetter, 62 Pa. D. \& C.2d 619, 624 (Northhampton County Ct. 1973) (finding patient's decision to refuse cancer surgery "irrational but competent").

151. Riga, supra note 134, at 124. This conclusion is in accord with the dissenting opinion of Justice (then Judge) Burger in In re President \& Directors of Georgetown College, 331 F.2d 1010 (D.C. Cir.), cert. denied, 377 U.S. 978 (1964). Commenting on Justice Brandeis's famous articulation of the "right to be let alone," see supra note 120, he said:

Nothing in this utterance suggests that Justice Brandeis thought an individual possessed

these rights only as to sensible beliefs, valid thoughts, reasonable emotions, or well-founded sensations. I suggest he intended to include a grcat many foolish, unreasonable and even absurd ideas which do not conform, such as refusing medical treatment even at great risk. Id. at 1017 (Burger, J., dissenting) (emphasis in original). 
tence; or treat the unreasonableness of a patient's decision to refuse treatment as conclusive evidence of her incompetence. These cases provide far less guidance, however, on the question of how courts should resolve the competence issue.

When a patient's refusal of treatment will clearly lead to death, and when the patient's family or doctors disagree with the patient strongly enough to bring the matter to court, the patient's decision will often appear to be a paradigm "bad" health care decision. But the court cannot directly evaluate the quality of that specific, isolated decision. If it did, the right of self-determination protected by the informed consent doctrine would become meaningless, having been reduced to the right to make inedical decisions that appear sensible or reasonable to the court.

On the other hand, courts cannot entirely disregard the substance of the treatment decision that calls the patient's competence into question, since her actual decision is clearly relevant to any evaluation of her decisionmaking ability. It is unreasonable to demand that courts determine competence without looking at the particular decision the patient wants to make. Competence is not an abstract characteristic independent of a person's actual situation and choices. People can be coinpetent to make some decisions and not others. A firm decision supported by readily understandable reasons may be competently made, even if the patient is senile or inentally ill. Conversely, the apparent senselessness of a patient's decision should prompt a stricter inquiry into competence. A judge must recognize this interdependence.

Thus, in evaluating a patient's competence, courts should not focus narrowly on the particular decision at issue, but neither should they disregard it. This is the competence dilemina. No definitive resolution of it appears to have been proposed by any court or commentator. ${ }^{152}$ This Comment addresses one aspect of this problem: How the already troublesome inquiry into competence is complicated when a patient's decision to refuse treatinent implicates the state's interest in preventing suicide, and how the test to determine patient competence should be revised to reflect this interest.

152. Shuitz notes only that '[d]etermining patients' decisionmaking capacity can be very problematic." Shultz, supra note 111, at 223 n.16. Meisel criticizes the courts for speaking about competence in "vague generalities," and states that most commentators have not made any serious effort "to devise a theoretical framework for the definition of incompetency or for the specification of criteria for the determination of incompetency." Meisel, supra note 114, at 440. See generally Roth, Meisel \& Lidz, Tests of Competency to Consent to Treatment, 134 AM. J. PsychiaTry 279 (1977) (describing five possible standards for determining competence). 
IV

\section{The Countervailing State InTerests}

The right to refuse treatment is not absolute; a finding of patient competence merely allows a court to balance that right against the countervailing state interests in preserving hife, protecting innocent third parties, protecting the integrity of the medical profession, and preventing suicide. ${ }^{153}$

These four interests would seem to cover all relevant state concerns, but they do not. Contemporary courts have not given the first three much weight in their balancing tests, and have virtually excluded the fourth interest-the state interest in preventing suicide-from their decisions. Using a technical distinction between passive refusals of treatment and direct acts of self-killing, they have summarily concluded that refusal of treatment sinply is not suicide. ${ }^{154}$ Hence, no court has addressed the nature and strength of the state's interest in preventing suicide in the refusal of treatment context. In fact, the only state imterest that consistently is given substantial weight $\mathrm{m}$ the balancing test is the imterest in preserving life, and even this interest generally has not been found compelling. ${ }^{155}$ Parts V and VI argue that the state interest in preventing suicide, in particular, deserves greater consideration in refusal of treatment cases. Before turning to that discussion, however, Part IV explains how courts have dealt with the other three state interests.

\section{A. Preserving Life}

The interest $m$ preserving life is the only state imterest that has been given substantial weight by the courts. ${ }^{156}$ This interest comprises two distinct interests: public welfare and the value of life for its own sake. ${ }^{157}$

153. See, e.g., Bartling v. Superior Court, 163 Cal. App. 3d 186, 193, 209 Cal. Rptr. 220, 224 (1984); Satz v. Perlmutter, 362 So. 2d 160, 162 (Fla. Dist. Ct. App. 1978); Brophy v. New England Sinai Hosp., 398 Mass. 417, 432-40, 497 N.E.2d 626, 634-38 (1986); In re Conroy, 98 N.J. 321, 34849, 486 A.2d 1209, 1223 (1985).

154. See infra text accompanying notes 188-93. Moreover, none of the other interests addresses the special concerns raised when a patient's refusal of treatment resembles suicide. Recognizing the inadequacy of the court's treatment of the other state interests, Justice Lynch dissented in Brophy on the grounds that the patient's refusal was suicidal, and that the majority's restrictive analysis of the applicable state interests had rendered the balancing test "all but chimerical." Brophy, 398 Mass. at 445-47, 497 N.E.2d at 642-43 (1986) (Lynch, J., dissenting).

155. One commentator has concluded that "there seems to be no clearly accepted societal interest which will justify complete denial of a competent adult's right to refuse lifesaving medical help." Riga, supra note 134, at 137.

156. Courts have distinguished between the state's interest in preserving life and its interest in preventing suicide. See, e.g., Bartling, 163 Cal. App. 3d at 195-96, 209 Cal. Rptr. at 225; Brophy, 389 Mass. at 438-39, 497 N.E.2d at 638; Conroy, 98 N.J. at 350, 486 A.2d at 1224.

157. Cantor, supra note 108 at 242-49; Comment, Unauthorized Rendition of Lifesaving Medical Treatment, 53 CALIF. L. REv. 860, 862, 867 (1965). Although courts have emphasized the importance of this state interest, they have generally concluded that it does not by itself outweigh the 
Some courts and commentators have argued that the public welfare interest alone is important enough to override a patient's refusal. One court has remarked that the state has a "substantial and compelling" interest in a "strong, healthy, robust, taxpaying citizenry" and that it has "a right to protect a person from himself and to demand that he protect his own life."158 The reasoming here is that the patient who refuses lifesavmg treatment harms the community by depriving it of a productive member.

This argument has been challenged on the ground that society does not normally compel individuals to realize their potential for social usefulness. ${ }^{159}$ Such compulsion is at odds with the ideal of individual freedom that guides American jurisprudence. As one judge put it, "The notion that the individual exists for the good of the state is . . . quite antithetical to our fundamental thesis that the role of the state is to ensure a maximum of individual freedom of choice and conduct."160 Moreover, it is not plausible that every patient who dies because she refuses treatment does substantial harm to society, simce most people who are terminally ill or seriously disabled would no longer be likely to produce tangible social benefits. ${ }^{161}$ For these reasons, and also because any judicial evaluation of the social worth of a patient who refused treatment would be unseemly, ${ }^{162}$ courts have instead focused on the second aspect of the state interest $m$ preserving life: the value of life for its own sake.

This interest im turn embraces two separate but related interests-in preserving respect for the sanctity of all life and in preserving as intrinsi-

patient's right to refuse treatment. See, e.g., Bartling, $163 \mathrm{Cal}$. App. 3d at 193-95, $209 \mathrm{Cal}$. Rptr. at 223-24. This Comment does not consider cases where the patient's refusal of treatment poses a danger to the public health and safety. E.g., McCartney v. Austin, 57 Misc. 2d 525, 293 N.Y.S.2d 188 (Sup. Ct. 1968) (state may require polio vaccinations as a precondition of admission to public school).

158. State ex rel. Swann v. Pack, 527 S.W.2d 99, 113 (Tenn. 1975) (denying that the free exercise clause creates a right to handle poisonous snakes in a religious ritual), cert. denied, 424 U.S. 954 (1976); see also Comment, supra note 157, at 866-67 (arguing that like polygamy, narcotics use, and the handling of poisonous snakes, refusal of treatment should be prohibited on social welfare grounds).

159. See Note, supra note 131 , at 1660-61.

160. In re Osborne, 294 A.2d 372, 375 n.5 (D.C. 1972); see also Riga, supra note 134, at 132 ("What social benefit would be more valuable than the individual's freedom of choice or right to determine what will happen to his body?").

161. Refusal of treatment might harm public morals, but that possibility need not be considered here. Insofar as the alleged harm is really moral harm (that is, detriment to the public respect for the value of life), it will be considered under the state's interest in preserving life for its own sake. And insofar as the alleged harm is the public's psychological outrage, the response is that personal freedom should not be substantially curtailed merely to spare the public's feelings. See the discussion of the religious refusal cases, supra notes 91.98 and accompanying text.

162. See Cantor, supra note 108, at 243. 
cally valuable the life of the individual patient. ${ }^{163}$ A special characteristic of refusal of treatinent cases suggests, however, that the state's interest in the sanctity of life does not justify overriding the patient's decision. There is a clash between the individual's interests and the interests of the state in protecting her, since the person refusing treatment is the very person that the state is trying to save. ${ }^{164}$ If individual autonomy and self-determination are themselves essential parts of what makes life valuable, then respect for the sanctity of hife would be disserved by failing to respect a patient's refusal. ${ }^{165}$

Courts in refusal of treatinent cases have qualified the concept of a state interest in preserving life in a way that partially answers this concern. Cases following Quinlan have focused on the quality of the patient's life and her potential for recovery, ${ }^{166}$ thus shifting the focus from the value of life in the abstract to the quality of the hife experienced by a particular patient. ${ }^{167}$ Thus, the state interest is strong when the patient can be restored to a qualitatively rich life and dimimishes when the patient is terminally ill or severely and painfully disabled. ${ }^{168}$ This

163. In re Conroy, 98 N.J. 321, 349, 486 A.2d 1209, 1223 (1985). In Bouvia, however, the court did not differentiate these two concerns, considering both under the rubric of the state's interest in preserving life. Bouvia v. Superior Court, 179 Cal. App. 3d 1127, 1142-43, 225 Cal. Rptr. 297, 304 05 (1986).

164. See Conroy, 98 N.J. at 349, 486 A.2d at 1223; Cantor, supra note 108, at 243; see also Note, Suicide and the Compulsion of Lifesaving Medical Procedures: An Analysis of the Refusal of Treatment Cases, 44 BROoKLYN L. REV. 285, 292 n.33 (1978) (recognizing that the state interest in life in the refusal of treatınent cases inay differ from the interest in Roe v. Wade, 410 U.S. 113 (1973) where the lives of two constitutionally protected subjects, the mother and the fetus, were at issue.).

165. Superintendent of Belchertown State School v. Saikewicz, 373 Mass. 728, 742, 370 N.E.2d 417, 426 (1977); Lane v. Candura, 6 Mass. App. Ct. 377, 378, 376 N.E.2d 1233, 1233 (1978); Conroy, 98 N.J. at 350, 486 A.2d at 1223-1224; Cantor, supra note 108, at 244.

166. The Quinlan court said, "[T] he state interest . . . weakens and the individual's right to privacy grows as the degrec of bodily invasion mcreases and the prognosis dins." In re Quinlan, 70 N.J. 10, 41, 355 A.2d 647, 664 (1976); accord Satz v. Perlmutter, 362 So. 2d 160, 162 (Fla. Dist. Ct. App. 1978); In re Welfare of Colyer, 99 Wash. 2d 114, 122-23, 660 P.2d 738, 743 (1983).

167. For exanple, the Brophy court stated that the state interest in life does not focus on "mere corporeal existence," but rather on the values of human dignity. Thus, if an incurable patient can only preserve his humanity by refusing invasive treatment and allowing natural death to occur, then this decision does not conflict with the state interest in hife. Brophy v. New England Sinai Hosp., 398 Mass. 417, 434, 497 N.E.2d 626, 635 (1986); see also Conroy, 98 N.J. at 366, 486 A.2d at 1232 (alternate standard for withdrawing treatment from an incompetent patient, besides the patient's own expressed or inferred desire to stop treatınent, is that the burdens of life with treatinent clearly outweigh its benefits, and continuing treatment would be inhumane).

168. Conversely, the strength of the patient's rights has sometimes been regarded as a matter of degree, increasing with the magnitude of bodily invasion imposed by the treatment. Saikewicz, 373 Mass. at 744, 370 N.E.2d at 427; Lane, 6 Mass. App. Ct. at 378 n.2, 376 N.E.2d at 1233 n.2; In re Quackenbush, 156 N.J. Super. 282, 290, 383 A.2d 785, 789 (App. Div. 1978). This factor, in most cases, is difficult to separate from concerns about the diminished quality of life that the patient will face even if such invasive treatment succeeds. Hence, it is not clear what difference it would have inade in these cases if the challenged treatment had been minimally invasive, such as the oral administration of lifesaving medication. 
shift of focus allows courts to avoid the untenable position of preserving an unwanted life of extreme suffering and loss of dignity.

Still, these cases have assessed the quality of a patient's life objectively, considering the patient's own opinion and desires as only one factor in such assessments. ${ }^{169}$ But they did not assert that the state cannot, in the name of sanctity of life, preserve a person's life against her will.

The Bouvia court went further, stating, "We do not believe it is the policy of this state that all and every life must be preserved against the will of the sufferer." 170 Bouvia has special significance because Bouvia's cognitive and commurncative abilities were intact and her condition was not terminal; thus the quality of her life appeared to be much better than that of a permanently comatose patient like Quinlan. The court nonetheless upheld lier refusal, focusing on two factors: her determination to die and lier subjective determination that her life was worthless. ${ }^{171}$ The Bouvia court took the patient's own estimate as the proper measure of ler "quahity of life." In doing so, it went beyond the Quinlan court's argument that the quality of life is diminished by the degree of mental and pliysical mcapacity. In the Bouvia court's view, the evaluation of the patient's quality of life sliould be left entirely to the patient. Yet in making the patient's own estimate the measure of her quality of life, the Bouvia court failed to confront the problematic fact that most suicidal persons will undervalue their lives. This Comment argues that courts sliould acknowledge the suicidal aspect of some refusals of treatment, and sliould frankly address the state's interest in preventing suicide.

\section{B. Protecting Innocent Third Parties}

The state's interest in protecting innocent third parties has generally come into play only when the patient has mimor children. The leading case is In re President and Directors of Georgetown College. ${ }^{172}$ In

169. The patients in Quinlan and Colyer were unconscious, and the patient in Conroy, though conscious, was in a severely impaired mental state. Their own evaluations of the quality of their lives were not in issue. In Satz, the court took account of the patient's statement that he was miserable and wanted the respirator removed, but based its decision on its independent conclusion that "the condition is terminal, the patient's situation wretched and the continuation of his life temporary and totally artificial." Satz, 362 So. $2 \mathrm{~d}$ at 162.

170. Bouvia v. Superior Court, 179 Cal. App. 3d 1127, 1143, 225 Cal. Rptr. 297, 305 (1986). Although no prior case has explicitly advanced this extreme view, several cases contain language that can be read to support it. See, e.g., Saikewicz, 373 Mass. at 744-45, 370 N.E.2d at 427 (the state's interest in life must be weighed against the physical and emotional burdens imposed on the patient by unwanted treatment, as well as against the patient's rights to privacy and bodily integrity); Conroy, 98 N.J. at 350, 486 A.2d at 1223 ("'T] he state's indirect and abstract interest in preserving the life of the competent patient generally gives way to the patient's much stronger personal interest in directing the course of his own life.").

171. Bouvia, 179 Cal. App. 3d at 1142, 225 Cal. Rptr. at 304.

172. 331 F.2d 1000 (D.C. Cir.), cert. denied, 377 U.S. 978 (1964); cf. Bartling v. Superior Court, 163 Cal. App. 3d 186, 195, n.6, 209 Cal. Rptr. 220, 225, n.6 (noting that state interest in protecting 
Georgetown, a Jehovah's Witness, the mother of a seven-month-old child, refused lifesaving blood transfusions on rehigious grounds. In authorizing an order permittimg the hospital to administer such transfusions as might be "necessary to save [her] life," 173 Judge Wright explamed the state's interest in keeping the mother ahve: "The state, as parens patriae, will not allow . . . this most ultimate of voluntary abandonments. The patient had a responsibility to the community to care for her infant." ${ }^{174}$

Judge Wright did not differentiate between the economic and emotional interests a child might have in the preservation of her mother's life. Commentators have argued that neither set of interests provides a solid rationale for state intervention. ${ }^{175}$ The economic reason for state intervention-to prevent surviving children from becoming dependent on state assistance-is factually contingent; it is absent where a child will have a surviving parent or other relative to care for her, or financial support from her parents' savings. ${ }^{176}$ Simce a refusing patient who has minor children usually will also have a spouse or relative able to assume her children's care, it is unlikely that this econormic concern will apply. It is also questionable whether the state has so strong an interest in the emotional well-being of children as to justify coercive intervention im their parents' treatment decisions. The law tolerates many situations, such as divorce, in which parents may imcidentally inflict einotional harm on their children free from state intervention. ${ }^{177}$

\section{Protecting the Integrity of the Medical Profession}

In denying patients the right to refuse treatment, courts in some of the early rehigious refusal cases based their decisions on the state's interest in protectimg the integrity of the medical profession. ${ }^{178}$ Recently,

third parties was not implicated by facts of that case). Though the interest is normally invoked only to protect a patient's minor children, an interesting exception is that in denying Bouvia's first request for judicial assistance in 1983, the judge emphasized the devastating effect that her choice to die would have on other handicapped persons and on other patients in the hospital. See Annas, supra note 10 , at 20 .

173. Georgetown, 331 F.2d at 1002.

174. Id. at 1008.

175. See, e.g., Cantor, supra note 108, at 252-53.

176. Id. at 253 .

177. Id. at 252 .

178. Those courts expressed two concerns: (1) Doctors and hospital staff would be forced to violate their professional obligation to preserve life by abandoning patients to die; e.g., John $F$. Kennedy Memorial Hosp. v. Heston, 58 N.J. 576, 582-83, 279 A.2d 670, 673 (1971); and (2) doctors and hospitals would be put in a vulnerable legal position-they could either treat a patient against her will or respect her refusal and allow her to die as a result of their failure to provide necessary medical care; e.g., id., at 582, 279 A.2d at 673; Georgetown, 331 F.2d at 1009 . The cases emphasized that the hospitals were involuntary hosts of refusing patients, and should not be required to resolve such problems of civil and criminal liability. See, e.g., Georgetown, 331 F.2d at 1007, 1009.

Under the interpretation of the informed consent doctrine prevailing at the time these cases were decided, a patient could not selectively refuse medical care once she had consented to some 
however, the influence of this interest has been diminished by two related developments.

First, medical ethics and practices have changed. As the Quinlan court discovered in its thorough inquiry into the modern treatment of debilitated terminal patients, contemporary medical ethics does not require that treatment be contmued when it offers no hope of recovery. ${ }^{179}$

Second, recent interpretations of the doctrine of informed consent have emphasized the patient's decisional autonomy, which places a limitation on doctors' duty and authority. ${ }^{180}$ Hence, even if traditional medical wisdom dictates that a patient should receive treatment, the patient's own interests and desires generally should prevail. ${ }^{181}$ The Satz court put this point forcefully:

It is all very convenient to insist on continuing [the patient's] life so that there can be no question of foul play, no resulting civil liability and no possible trespass on medical ethics. However, it is quite another matter to do so at the patient's sole expense and against his competent will, thus inflicting never ending physical torture on his body until the inevitable, but artificially suspended, moment of death. Such a course of conduct invades the patient's constitutional right of privacy, removes his freedoin of choice and invades his right to self-determination. ${ }^{182}$

The state's interest in protecting the integrity of medicine is no longer an important element in the balancing test, and will remain unim-

treatment. This view was reiterated when Bouvia first sought judicial assistance in 1983 . The court stated that established ethics of the medical profession outweighed Bouvia's right of selfdetermination. In the court's view, the hospital had "no reasonable option" other than force-feeding in order to save an otherwise nonterminal patient from self-starvation. See Annas, supra note 10, at 20.

179. In re Quinlan, 70 N.J. 10, 42-51, 355 A.2d 647, 664-69 (1976). The Quinlan court concluded "that physicians distinguish between curing the ill and comforting and easing the dying; that they refuse to treat the curable as if they were dying or ought to die, and that they have sometimes refused to treat the hopeless and dying as if they were curable." Id. at 47,355 A.2d at 667.

180. See supra notes 113-19 and accompanying text.

181. See, e.g., In re Conroy, 98 N.J. 321, 352-53, 486 A.2d 1209, 1225 (1985) (informed consent only has meaning if it is respected even when it conflicts with doetor's advice or values of the medical profession); Bartling v. Superior Court, 163 Cal. App. 3d 186, 195, 209 Cal. Rptr. 220, 225 (1984) (patient's rights must be "paramount to the interests of the patient's hospital and doctors"); Superintendent of Belchertown State School v. Saikewiez, 373 Mass. 728, 744, 370 N.E.2d 417, 427 (1977) (if patient's right to refuse treatment is founded in right to bodily integrity and control of one's own fate, then it is "superior to the institutional considerations"); see also Cantor, supra note 108, at 250 ("Unfettered exercise of medical judgment has never been a sacrosanct value. The doctrine of informed consent is grounded on the premise that a physician's judgment is subservient to the patient's right to self-determination.").

182. Satz v. Perlmutter, 362 So. 2d 160, 164 (Fla. Dist. Ct. App. 1978). See also Bouvia v. Superior Court, 179 Cal. App. 3d 1127, 1143, 225 Cal. Rptr. 297, 305 (1986) (emphatically denying that the interests of the medical profession limit the patient's right to refuse treatment: "Elizabeth Bouvia's decision to forego medical treatment or life-support through a mechanical means belongs to her. It is not a medical decision for her physicians to make. . . It is not a conditional right subject to approval by ethics committees or courts of law."). 
portant unless courts unexpectedly reverse this doctrinal trend. ${ }^{183}$

\section{$\mathrm{V}$}

\section{The State Interest IN Preventing Suicide}

The state interest in preventing suicide derives from the state interest in preserving life. ${ }^{184}$ Although suicide is no longer a crime, the interest in preventing it still finds expression im statutory provisions indicating civil commitinent for atteinpted suicide, and in criminal sanctions for aiding and abetting suicide. ${ }^{185}$ Although at least one court has questioned whether this interest is worthy of consideration independent of the interest in preserving life, ${ }^{186}$ the two are generally kept analytically distinct in the refusal of treatment cases. ${ }^{187}$

Courts in refusal of treatinent cases have devalued the state interest in preventing suicide by drawing a categorical distinction between suicide and refusals of treatment. This Part outlines the narrow definition of suicide prevailing in current doctrine, explores the policy concerns underlying it, and concludes that courts should redefine the state interest in preventing suicide so as to inake it a substantial factor to be weighed in refusal of treatment cases.

\section{A. The Prevailing Narrow Definition of Suicide}

Most of the refusal of treatment cases have avoided directly balancing the state interest in preventing suicide against the patient's right to refuse treatinent simply by holding that the refusal of treatment does not fall within the definition of suicide. The comınon law definition of suicide, as these cases interpret it, requires both specific intent to kill oneself and an affirmative act setting in motion the cause of death. ${ }^{188}$ Because the courts have seen patients who refuse treatment as intending only to

183. Cases of suicidal refusals of treatment raise a related issue concerning doctors' authority and responsibility. For example, a doctor who respects a patient's refusal of treatment might be said to be aiding and abetting suicide. But if such a patient ultimately has the right to bring about her own death by refusing treatment, it could be argued that she also has a right to medical assistance in ending her life more quickly and painlessly. See, e.g., Bouvia, 179 Cal. App. 3d at 1147, 225 Cal. Rptr. at 307 (Compton, J., concurring). Although related to the topic of this Comment, these issues are outside its scope.

184. Note, supra note 164 , at $294-95$ ("[T] he notion that the government may prohibit acts of attempted suicide is . . . virtually unassailable.").

185. Conroy, 98 N.J. at 350, 486 A.2d at 1224; see infra notes 238-44 and accompanying text.

186. Conroy, 98 N.J. at 350, 486 A.2d at 1224.

187. See, e.g., Bartling v. Superior Court, 163 Cal. App. 3d 186, 195-96, 209 Cal. Rptr. 220, 225 (1984); Conroy, 98 N.J. at 350, 486 A.2d at 1224.

188. Bartling, 163 Cal. App. 3d at 196, 209 Cal. Rptr. at 226; Satz v. Perlmutter, 362 So.2d 160, 162-63 (Fla. Dist. Ct. App. 1978); Brophy v. New England Sinai Hosp., 398 Mass. 417, 439, 497 N.E.2d 626, 638 (1986); Superintendent of Belchertown State School v. Saikewicz, 373 Mass. 728, 743 n.11, 370 N.E.2d 417, 426 n.11 (1977); Conroy, 98 N.J. at 350, 486 A.2d at 1224; In re Lydia E. Hall Hosp., 166 Misc. 2d 477, 486-87, 455 N.Y.S.2d 706, 711-12 (Sup. Ct. 1982); In re Colyer, 99 
avoid unwanted treatment, pain, or the violation of their religious principles - and not to cause their own deaths-they have considered the specific intent element to be lacking. ${ }^{189}$ And since courts have considered the underlying disease or injury - and not the withholding or cessation of treatinent - to be the cause of death, they have not considered suicidal refusals to be affirmative acts causing death. ${ }^{190}$

The few courts that have considered the underlying policy reasons for this state interest have hastily concluded that the policy behind preventing suicide is to avoid irrational self-destruction. ${ }^{191}$ They then reason that because the decision of a coinpetent patient to forego treatment "when death is inevitable and the treatment offers no hope of cure or preservation of life" is not irrational self-destruction, the state's interest in preventing suicide is not implicated. ${ }^{192}$ This superficial analysis leaves open the question whether a competent, nonterminal patient's refusal of treatment that could improve or stabilize her condition should be treated as suicide.

The Bouvia court dodged the suicide issue by summarily distinguishing Bouvia's resignation "to accept an earlier death" and "allow nature to take its course" from suicide. ${ }^{193}$ Instead, the court should have taken that opportunity to go beyond the superficial definitional distinctions and perfunctory policy discussions yielded by other cases.

Wash. $2 \mathrm{~d} 114,123,660$ P.2d 738, 743 (1983). This definition originated when suicide and attempted suicide were criminal acts.

189. The Conroy court reasoned that recognizing a right to refuse treatment respects the patient's intent, not to die, but to live free from unwanted medical intervention, and to choose a "'personally preferred manner of concluding life" " (quoting Note, The Tragic Choice: Termination of Care for Patients in a Permanent Vegetative State, 51 N.Y.U. L. REv. 285, 310 (1976)). 98 N.J. at 351, 486 A.2d at 1224. Similarly, In re Quinlan, 70 N.J. 10, 43, 355 A.2d 647, 665 (1976) and Bartling, 163 Cal. App. 3d at 196, 209 Cal. Rptr. at 226 recognized a distinction between selfdestruction and "self-determination against artificial life support or radical surgery," and in Lydia, 116 Misc. $2 \mathrm{~d}$ at 488,455 N.Y.S.2d at 712 , the court found that the patient's decision was based on a desire to avoid pain and on church teaching, not on suicidal intent.

190. The Conroy court held that if the patient allowed the disease to take its course, her death would primarily be the result of the underlying disease, not of self-inflicted injury. 98 N.J. at 351, 486 A.2d at 1224. Similarly, the Bartling court characterized disconnecting the patient's respirator as merely hastening a natural death. $163 \mathrm{Cal}$. App. 3d at 196, 209 Cal. Rptr. at 226; accord Satz, 362 So. 2d at 162; Saikewicz, 373 Mass. at 743 n.11, 370 N.E.2d at 426 n.11; Colyer, 99 Wash. 2d at 123, 660 P.2d at 743 .

191. See Bartling, 163 Cal. App. 3d at 196, 209 Cal. Rptr. at 226; Saikewicz, 373 Mass. at 743 n.11, 370 N.E.2d at 426 n.11; Lydia, 116 Misc. 2d at 487,455 N.Y.S.2d at 712 . One court briefiy stated a more substantive rationale: that the general policy of protecting individual liberty supports a patient's refusal, whether or not the refusal amounts to suicide. Erickson v. Dilgard, 44 Misc. $2 \mathrm{~d}$ 27, 28, 252 N.Y.S.2d 705, 706 (Sup. Ct. 1962) (Jehovah's Witness's refusal of blood transfusion upheld).

192. Saikewicz, 373 Mass. at 743 n.11, 370 N.E.2d at 426 n.11; see also Riga, supra note 134, at 135 (arguing that since patients who refuse lifesaving medical procedures are generally not irrational, the reasons for the state interest in preventing suicide do not apply).

193. Bouvia v. Superior Court, 179 Cal. App. 3d 1127, 1144, 225 Cal. Rptr. 297, 306 (1986). 


\section{B. Policy Concerns Underlying the Prevailing Definition}

The argument that the patient who refuses treatment lacks specific intent to kill herself, and therefore is not committing suicide, may reflect a judicial unwillingness to distingnish "good" from "bad" reasons for patients' treatinent decisions. ${ }^{194}$ This reluctance may arise from the modern view that the inforined consent doctrine, if it is to confer any meaningful rights on patients, must protect foolish and irrational decisions as well as reasonable ones. ${ }^{195}$ It may also reflect courts' use of constitutional privacy analysis in defining the basis for the patient's right to refuse treatment. ${ }^{196}$ Even the soinetimes artificial distimction between the act of suicide and the passive exercise of the right to refuse lifesaving treatment may rest on a genume concern with preserving individual freedom to make unorthodox decisions. ${ }^{197}$

The distinction between affirmative acts causing death and passive refusals of hifesaving treatment also reflects a general jurisprudential principle that the law should primarily prohibit misfeasance as opposed to nonfeasance. ${ }^{198}$ While we commonly accept limitations on individual liberty that prevent people from performing dangerous actions, we usually consider affirmative requirements that people engage in beneficial acts to be overly restrictive. ${ }^{199}$ Further, the passive, fatahistic stance of a

194. See Marzen, O'Dowd, Crone \& Balch, Suicide: A Constitutional Right? 24 DuQ. L. REv. 1, 12-13 (1985). In the context of a general argument that there is no constitutional right to suicide, and that state policies against suicide should be maintained, these authors argue that although it may sometimes be just as morally wrong to refuse treatment as it is to commit suicide, the law should regulate conduct only, and not challenge people's motives for nonprohibited actions such as refusal of treatment.

195. See supra notes $146-51$ and accompanying text.

196. See supra notes $120-27$ and accompanying text.

197. This underlying conccrn with individual liberty was expressed in one decision that upheld the patient's refusal:

The county argues that it is in violation of the Penal Law to take one's own life and that as a practical matter the patient's decision not to accept blood is just about the taking of his own life. The court cannot agree.... [I]t is the individual who is the subject of a medical decision who has the final say and . . . this must necessarily be so in a system of government which gives the greatest possible protection to the individual in the furtherance of his own desires.

Erickson v. Dilgard, 44 Misc. 2d 27, 28, 252 N.Y.S.2d 705, 706 (Sup. Ct. 1962).

198. Marzen, O'Dowd, Crone \& Balch, supra note 194, at 10-11; see Buch v. Amory Mfg. Co., 69 N.H. 257, 261, 44 A. 809, 811 (1898) (stating that there is "a broad gulf" between the legal duty not to do affirmative harm and the possible moral duty to protect someone from injury); W. Prosser, THE LAW OF TORTS $\S 56$, at 373-74 (5th ed. 1984) (distinction between misfeasance and nonfeasance); see also T. GREY, THE LEGAL ENFORCEMENT OF MORAL1TY 156 (1983) (recognizing that the distinction is fundamental in law, but questioning whether is it always morally siguificant).

199. Riga argues, "It is one thing for the state to impose an affirmative duty to take certain minimum measures to stay alive. .. . But it is another theory of jurisprudence which would empower the state to impose on citizens an affirmative legal duty to make use of highly developed medical techniques in order to prolong life." Riga, supra note 134, at 133; see also Byrn, Compulsory Lifesaving Treatment for the Competent Adult, 44 FoRDHAM L. REv. 1, 21 (1975) (arguing that the governmental function of protecting life should extend only as far as preventing the active 
patient who allows an injury or disease to overtake her seems less disrespectful of the sanctity of life than the act of a person who violently kills herself. ${ }^{200}$

The courts' unwillingness to coerce patients to accept treatmentthat is, to prohibit their nonfeasance-also reflects the common law protection of bodily integrity. ${ }^{201}$ The patient's interest in being free from unconsented touching protects her froin beneficial interference with her self-neglect just as it protects her from harmful touching. Furthermore, the patient's interest in maintaining those "zones of privacy" protected by the constitutional right of privacy is arguably relevant to personal decisions concerning inedical crises, death, and dying. ${ }^{202}$

The similarity of refusal of treatment to suicide in cases like Bouvia calls for judicial explication of the reasons for distinguishing the two situations. Once elucidated, however, these underlying reasons still might not be persuasive.

\section{Critique of the Prevailing Definition}

In some refusal of treatment cases, the patients' apparent motives were indistmguishable from suicidal intent-a fact that casts doubt on the courts' imsistence that patients who refuse treatment lack the specific intent required by the common law definition of suicide. Bouvia, in her 1983 case, stated plainly that she intended to starve herself to death. ${ }^{203}$ More recently, the trial court in Bouvia v. Superior Court found that she had formed an mtent to die and had purposefully engaged in a selective refusal of inedical treatment to accomplish that goal. ${ }^{204}$ Although Bouvia maintained that she intended to eat all she could physically tolerate, and that her goal was merely to avoid the unwanted inedical intervention of feeding tubes, the concurring opimion in the court of appeal decision claimed that Bouvia had had to "stultify her position before [that] court by disavowing her desire to end her life" in order to make her decision fit better within established refusal of treatment doctrine. ${ }^{205}$

Likewise, the elderly patient in Lane $v$. Candura refused a lifesaving operation for reasons that many people give as reasons to commit sui-

destruction of life); Note, An Adult's Right to Resist Blood Transfusions: A View Through John F. Kennedy Memorial Hospital v. Heston, 47 Notre DAME LAw. 571, 586 (1972) (arguing that there is no moral or legal duty to undergo medical treatment to prolong one's life).

200. See Byrn, supra note 199, at 20-21 (arguing that refusal of treatment shows a fatalistic attitude, of deferring to the vagaries of life, far removed from the extreme forms of aggression of suicidal persons who make war on their own lives; thus it does not undermine society's concept of the sanctity of life).

201. See supra notes $108-12$ and accompanying text.

202. See supra notes $125-26$ and accompanying text.

203. See Bouvia v. Superior Court, 179 Cal. App. 3d 1127, 1136, 225 Cal. Rptr. 297, 300 (1986).

204. Id. at 1144, $225 \mathrm{Cal}$. Rptr. at 305.

205. Id. at 1147, 225 Cal. Rptr. at 307 (Compton, J., concurring). 
cide. Her reasons were that she had been unhappy since her husband's death, that she did not want to be a burden to her children, that she did not want to live as an invalid in a nursing hoine, and that she did not fear death but welcoined it. ${ }^{206}$ These same reasons account for many active suicides among elderly people. ${ }^{207}$

One inight reply to the assertion that some refusals of treatinent are motivated by suicidal intent by arguing that the law should not inquire into a patient's subjective motives. But then, the law must infer a patient's intent from her conduct, and her act of refusing lifesaving treatment rather starkly indicates her imtent to bring about her own death. ${ }^{208}$ Those who would mamtain a distinction between refusal of treatment and suicide cannot rest on the argument that the law should not scrutinize subjective motives, unless the distinction between actively causing one's own death and passively refraining froin treatment is viable. If it is, then a compelling argument can be made that the law should not scrutinize the motives for otherwise lawful conduct, and therefore that patients who refuse treatment should not be presumed to be engaged in irrational self-destruction. Thus, the specific intent element depends upon the active-passive distinction.

Cases involving patients' refusal of feeding tubes, however, cast doubt on this distinction. Most courts have considered feeding tubes to be no different from other means of lifesaving treatment that patients have the right to refuse. ${ }^{209}$ But when the patient is competent and able to

206. Lane v. Candura, 6 Mass. App. Ct. 377, 381, 376 N.E.2d 1232, 1234 (1978).

207. Patel, Pathology of Suicide, 13 MED. SCI. \& L. 103, 104-05 (1973) (empirical study finding that suicides in elderly age group were neither insane, mentally abnormal, nor temporarily irrational, but had lost a loved one or suffered from physical afflictions or social and economic hardships). The same may be true of elderly patients who refuse lifesaving treatment. See Heilman \& Thompson, supra note 12, at 14 (describing an unreported case of a competent and intelligent man in a nursing hoine who fasted to speed his death; the judge, although he personally disapproved of the man's decision, refused to allow force-feeding).

208. One commentator argues that since " $[\mathrm{t}] \mathrm{he}$ law is generally incapable of looking at intent except by way of an analysis of observed behavior and its consequences," both active suicides and refusals of lifesaving treatment should be prevented on the basis of presumed suicidal intent, and to treat the two situations differently would be senseless and unfair. Sherlock, For Everything There is a Season: The Right to Die in the United States, 1982 B.Y.U. L. Rev. 545, 557; see also G. Williams, THE SANCTITY OF LIFE AND THE CRIMINAL LAw 286 (1957) (arguing that because in law, intention is generally inferred from conduct, soineone who appears to be seriously attempting suicide should be presumed to have the specific intent required for criminal liability whether or not she really wanted to die); Note, supra note 164, at 307 (pointing out the presumption in the criminal law that people intend the natural and necessary consequences of acts they deliberately perform).

209. The Conroy court noted that some commentators have distinguished between artificial feedings and other forms of treatment, but found that this distinction rested not on any principled distinction, but on the emotional symbolism of food and water. In re Conroy, 98 N.J. 321, 372-73, 486 A.2d 1209, 1235-36 (1985); accord Bouvia v. Superior Court, 179 Cal. App. 3d 1127, 1137, 225 Cal. Rptr. 297, 300 (1986); Barber v. Superior Court, 147 Cal. App. 3d 1006, 1016, 195 Cal. Rptr. 484, 490 (1983); Brophy v. New England Sinai Hosp., 398 Mass. 417, 436-38, 497 N.E. 2d 626, 63637 (1986). 
eat, ${ }^{210}$ her refusal to eat deprives her body of a vitally needed substance that is never self-generating, thereby setting in motion the cause of death-starvation..$^{211}$ Some courts have reasoned this way in cases denying that a prisoner has the right to starve to death unhindered. ${ }^{212}$

But to exclude self-starvation from the theory that refusing medical treatment is not actively killing oneself is problematic. There are other situations in which a patient's refusal of a minimally invasive lifesaving treatment could be seen as an intervening active cause of her own death. Pernicillin, snakebite serum, and, in the case of diabetics, insulin, are not automatically generated by the human body any more than food is. ${ }^{213}$

More generally, as the Conroy court pointed out, "[c] haracterizing conduct as active or passive is often an elusive notion," and consequently, determining whether conduct is an act or an omission does not always establish whether it is morally or legally permissible. ${ }^{214}$ Simi-

210. A case may be further complicated, as was Bouvia, when it is unclear whether the patient is unable or unwilling to eat. See supra note 16 and accompanying text.

211. The court in Bouvia v. County of Riverside did not regard food and water as medical treatment that the patient could refuse, but as means of preventing attempted suicide. Bouvia v. County of Riverside, No. 157280 (Cal. Super. Ct. Riverside Co., Dec. 16, 1983); see Note, Withholding Food and Water from a Patient-Should it be Condoned in California?, 16 PAC. L.J. 877,884 (1985). The Note's author argues that the right to refuse treatment does not give a patient the right to starve to death with medical assistance, and that the decision in Barber v. Superior Court must be limited to its facts: an incompetent, terminally ill patient, unable to eat, who did not initiate the causes of his condition. Id. at 891-93. The author distinguishes respirators, dialysis, and other artificial life-support from medical nutrition on the ground that the healthy human body automatically performs functions such as breathing and pumping and cleansing the blood, so that if the patient dies when artificial support is removed, the cause of death is the failure of his discased body to perform its natural functions, not the withdrawal of treatment. Id. at 893 .

212. See Van Holden v. Chapman, 87 A.D.2d 66, 70, 450 N.Y.S.2d 623, 627 (1982) (permitting force-feeding of prisoner on hunger strike: "Even superficial comparison of the right to decline medical treatment with the right to take one's life [by starvation] illustrates their essential dissimilarity and to argue that because the State has recognized the former it must permit the latter would be to engage in the most specious reasoning."). In In re Caulk, 125 N.H. 226, 480 A.2d 93 (1984), the court distinguished a prisoner's refusal to cat from the patient's right to refuse medieal treatment on the ground that the prisoner had set the death-producing agent in motion with the specific intent of causing his death, and held that the state's interests in preserving life and in preventing suicide thus predominated over his right to refuse medical intervention. $I d$. at 232,480 A.2d at 97. This rcasoning was challenged in a dissenting opinion, which argued that there is a qualitative difference between suicide and the prisoner's choice to allow his death to oceur by fasting until natural death, so as to die with dignity. Id. at 236, 480 A.2d at 100 (Douglas, J., dissenting).

213. The appeal to natural causes of death to distinguish suicide from refusal of treatment is well answered by a commentator on suicide in general: "Not doing anything is doing something; it is a decision to act every bit as much as deciding for any other deed. If I decide not to eat or drink anymore, knowing what the consequence will be, I have committed suicide as surely as if I had used a gas oven." J. Fletcher, Humanhood: Essays IN B1OMEdical Ethics 157 (1979). Thus, when a patient decides to die by refusing treatment, "nature" has made no decision for the person. Moreover, in some cases a person can in fact initiate what appears to be a natural eause of death. Note, supra note 164, at 304

214. In re Conroy, 98 N.J. 321, 369, 486 A.2d 1209, 1234 (1985). Moreover, in two cases concerning religious refusals, the courts diverged from the usual definitional preclusion of the suicide issue. The Georgetown court swept aside the specific intent and misfeasanee-nonfeasance distinctions 
larly, the President's Commission for the Study of Ethical Problems in Medicine has concluded that, in physicians' decisions about life-sustaining treatment, technical distinctions between acts and omissions that cause death should not take the place of substantive analysis. ${ }^{215}$ Finally, the distinction may simply violate conimon sense. If someone walks out into a blizzard to die, he conımits suicide. Surely he also commits suicide if, caught outdoors in a blizzard, he refuses to conie in. ${ }^{216}$

The dissenting opinions in Brophy applied this reasoning to the suicidal refusal issue. They argue that the state interest in preventing suicide deserves substantive analysis and that the majority was wrong in finding that niterest mapplicable in refusal of treatment cases. Justice Lynch stated that when a patient (or her surrogate decisionmaker) refuses food and water with the purpose of ending a hife that is "over," "the death producing agent would be set in motion by a volitional act with the intent to cause death." 217 In some cases, then, suicide must "also be conceived as an act of omission." 218 Further, the patient's purpose ${ }^{219} \mathrm{im}$ refusing treatment would not be to avoid useless, imvasive, and humiliating treatment, but rather to end a life she considers not worth living. ${ }^{20}$ Thus, she would not lack of specific imtent to die, and her

and concluded that where suicide is illegal by common law or statute, the patient may not refuse lifesaving medical assistance: "Only quibbles about the distinction between misfeasance and nonfeasance, or the specific intent necessary to be guilty of attempted suicide, could be raised against this latter conclusion." In re President and Directors of Georgetown College, 331 F.2d 1000, 1009 (D.C. Cir.), cert. denied, 377 U.S. 978 (1964). Similarly, the Heston court concluded that whatever state interests justify intervention in attempted suicide also support the overriding of a patient's refusal of lifesaving treatment. John F. Kennedy Memorial Hosp. v. Heston, 58 N.J. 576, 581-82, 279 A.2d 670, 673 (1971); see also Cantor, supra note 108, at 233-34. Heston was explicitly overruled on this point by Conroy, 98 N.J. at 351,486 A.2d at 1224.

215. President's Comm'N for the Study of Ethical Problems in Medicine and Biomedical and Behavioral Research, Deciding to Forego Life-Sustaining TREATMENT 4 (1983). Both the authors of this report and the Conroy court considered the actomission problem in the context of inquiring whether it is ever permissible for a doctor to take affirmative action to end a patient's life, and what constitutes an affirmative act as opposed to an omission of treatment. However, the point applies equally to the question of the patient's own acts and omissions.

216. Comment, supra note 157 , at 868 . That the distinction between misfeasance and nonfeasance in causing one's own death can lead to absurd results was recognized long before the refusal of treatment cases, as shown by the discourse of a gravedigger in HAMLET: "Here lies the water-good. Here stands the man-good. If the man go to this water and drown himself, it is [suicide], will he nill he, he goes; mark you that. But if the water come to him and drown him, he drowns not himself." SHAKESPEARE, HAMLET, act V, scene I, lines 13-17.

217. Brophy v. New England Sinai Hosp., 398 Mass. 417, 447, 497 N.E.2d 626, 642 (1986) (Lynch, J., dissenting in part).

218. Id. Otherwise, Justice Lynch pointed out, the majority would also be compelled to recoguize a right to self-starvation at home, or otherwise outside a medical setting. Id. at 447 n.5, 497 N.E.2d at 643 n.5 (Lynch, J., dissenting in part).

219. That is, the purpose ascribed to the patient under the doctrine of substituted judgment. See supra note 70 and accompanying text.

220. Brophy, 398 Mass. at 450, 498 N.E.2d at 644 (O'Connor, J., concurring in part and 
refusal could be deemed suicidal.

The specific intent element and the active-passive distinction are thus crucial factors in determining the outcome of refusal of treatment cases because they block substantive analysis of the only potentially compelling state interest-the interest in preventing suicide. Because none of the other state interests is generally compelling, anyone who wishes to die and who has a potentially fatal illness or injury apparently can avail herself of the right to refuse treatment. ${ }^{221}$

Patients like Bouvia cannot be distinguished categorically from others who attempt suicide on grounds of specific intent. According to one commentator, Bouvia "did not seek to refuse medical interventions she found personally intolerable; she sought to end her hfe because she found hiving intolerable." 222 Moreover, in cases where a patient has set in motion the cause of his death, either by creating a life-threatening medical condition or by refusing minimally invasive treatment, the distinction between misfeasance and nonfeasance is unconvincing. ${ }^{223}$ If there are good reasons for state intervention with ordinary, active suicides, these are also reasons for limiting a suicidal patient's right to refuse treatment. $^{224}$

dissenting in part). Justice O'Connor distinguished Brophy's case from Conroy and Saikewicz, where the patients rejected invasive treatinent that, at best, could only prolong their lives for a brief and uncertain period. In contrast, Brophy chose to die not because of the invasiveness of the treatment, but because he considered an artificially prolonged life intolerable. Id. at 449, 498 N.E.2d at 644 ( $O^{\prime}$ Connor, J., concurring in part and dissenting in part).

221. A narrowly circuinscribed definition of suicide, establishing artifieial boundaries, might be justified in the context of criminal hability, but in the refusal of treatment cases the question is not whether the patient is guilty of a crime. See Comment, supra note 157, at 870 ("the concern is not whether the individual is 'guilty' of his own death but rather with the preservation of his life"); see also J. FLETCHER, supra note 213, at 156:

Acts of deliberate omission are morally not different from acts of commission. But in the Anglo-American law, it is a crime to push a blind man off a cliff. It is not, hovever, a crime to deliberately not lift a finger to prevent his walking over the edge. This is an unplcasant feature of legal rcasoning which is alien to ethics and to a sensitive conscience.

Such narrow reasoning is necessary in criminal law but inappropriate in legal analysis of policy issues.

222. Annas, supra note 10, at 21.

223. Cantor, supra note 108 , at $255-56$ \& n.133; Comment, supra note 157 , at 868 . Although Cantor's general thesis is that even suicidal patients should be allowed to refuse treatment, he stresses that the narrowness of the technical legal definition of suicide, and the exclusion of refusal of treatinent froin that definition, do not refute "the arguments of those who assert that the same interests supporting governmental intervention to block suicide also support judicial intervention to compel medical treatment." Cantor, supra, at 255; see also Sherlock, supra note 208, at 554-58 (arguing that distimctions between suicide and refusal of treatment-which he calls "voluntary passive euthanasia"-overlook the crucial fact that in both cases the patient has decided to die, and concluding that if ordinary suicides should be prevented, so should fatal refusals of treatment); Note, supra note 164, at 314 (urging that judicial balancing of patients' rights to refuse treatment against state interests should not be based on whether the patient has acted out the various elements of a particular definition of suicide).

224. See Cantor, supra note 108, at 255-56; Note, supra note 164, at 294. 
A simple dichotomy between nonsuicidal patients who have a fundamental right to self-determination and suicidal patients who have no such right and can be coerced for their own good is also inappropriate..$^{225}$ Instead, in the case of a patient whose refusal of treatment strongly resembles suicide, the policy reasons for preventing suicide should be weighed into the balance between the patient's and the state's interests. Hence, we must ask what those policy reasons are, and how they can be incorporated into the balancing test $\mathrm{i}$ refusal of treatment cases.

\section{VI}

\section{The State Interest in Preventing Suicide REEXAMINED}

\section{A. The Traditional Basis for Preventing Suicide: Morality}

A brief look at the evolution of moral and legal views on suicide will facilitate an understanding of the state's traditional interest in preventimg suicide. ${ }^{226}$ Suicide raises inajor issues both im ethical and political philosophy and in law. ${ }^{227}$ The relationship between moral and legal questions concerning suicide is crucial. If suicide were always morally wrong, there would be a simple, solid basis for a state pohicy to prevent it. But if a reasoned challenge can be made to the position that suicide is categorically morally wrong, then moral disapproval alone cannot legitimate a state policy against suicide. The longstanding, serious, and sustamed moral disagreement over suicide suggests that someone could rationally decide to commit suicide, beheving that it is morally right. ${ }^{228}$

The three strongest traditional moral arguments agamst suicide

225. Annas argues that although Bouvia's conduct cannot convincingly be differentiated from suicide, it is also inadequate simply "to dismiss Ms. Bouvia's self-destructive desire as suicide and thereby remove her right to refuse medical intervention." Annas, supra note 10, at 21; see also Note, supra note 164, at 315 (arguing that even if refusal of treatment falls within a broader definition of suicide, patient's privacy rights should still be weighed against state interests).

226. This Part will first consider suicide in general, and then return to the special case of suicidal refusal of treatment. This Comment assumes that the state interest in preventing suicide is the same in refusal of treatment cases as in active suicides. This assumption is debatable, however, because in the refusal of treatment cases the state is not merely leaving a person alone to kill himself, but intervening to prevent doctors from saving his life. The difference, however, exists merely because patients are helpless and cannot escape supervision and control. The state must intervene so that patients will have the same degree of autonomy as able-bodied persons; otherwise, the dispute will be resolved simply by the balance of power between the patient and his family or doctors.

227. "[Suicide] raises the marital disputes of order and freedom, effort and indulgence, holiness and happiness, authority and conscience." G. WILliams, supra note 208, at 248.

228. For a general overview of moral debate about suicide, see G. WILliams, supra note 208, at 248-310; Beauchamp, Suicide, in MATTERS OF LIFE AND DEATH 67 (T. Regan ed. 1980); Hook, The Ethics of Suicide, 37 INT'L. J. ETHICs 173 (1927); Smith \& Perlin, Suicide, in 4 ENCYCLOPEDIA OF Bioethics 1618 (1978); Williams, Suicide, in 8 Encyclopedia of Philosophy 43 (1968). 
assert: (1) that it shows disrespect for human life, ${ }^{229}$ (2) that it violates one's duties to contribute to society, ${ }^{230}$ and (3) that it wrongs one's friends and family by hurting them emotionally and by depriving them of support and compamionship. ${ }^{231}$

Recent case law, however, suggests counterarguments to each of these, and raises doubts about whether this reasoning would convince courts in future refusal of treatment cases that suicide is categorically wrong.

First, it is arguable that one need not respect life itself, but rather the qualities of a particular life that make it worth living. ${ }^{232}$ If, as a result of illness or other misfortune, a person's subjective enjoyment of her life is so diminished that life is a burden to her, she may end it without showing disrespect for her own humanity. ${ }^{233}$

Second, if suicide is wrong because it deprives society of an individual's contributions, it is a relatively minor wrong. It is implausible to suppose that everyone is so essential to society that anyone's refusal to contribute further constitutes a grave public harm. ${ }^{234}$ Moreover, the devotion of modern democratic society to the protection of individual liberty would oppose the creation of a social duty to live. ${ }^{235}$

229. See I. Kant, Foundations of the MEtaphysics of Morals 39-40, 47-48 (Macmillan ed. 1985) (1785).

230. Plato expressed the view that rationally chosen suicide is a flagrant act of contempt for the state and an abandonment of one's duty to society, but is excusable when committed impulsively, out of insanity or suffering. Plato, LAws $* 873 \mathrm{c}$-e. Aristotle also took this view, ARISTOTLE, NichomacheaN Ethics Book 5, $\S 11$ (H. Rackham rev. ed. 1934), as did Aquinas. Aquinas, Whether it is Lawful to Kill Oneself, in ETHICAL Issues IN DEATH AND DyING 102 (T. Beauchamp and S. Perlin eds. 1978). See Marzen, O'Dowd, Crone \& Balch, supra note 194, at 135 ("[T]hc theory of loss of one individual as a blow to the larger community appears to be a universal one.").

231. Hook, supra note 228, at 181-82.

232. See supra notes 166.68 and accompanying text.

233. Fletcher argues that:

The basic issue is whether quality of life is more valuable than life qua life. ...

One's life is a value to be perceived in relation to other values. . . . Without life, other things are of no value to us, but by the same token, without other things, life may be of no value to us. ... .

[H]uman beings ... do not regard life as an end in itself. Life to be up to human standards has to integrate a number of other values, to make it worth our while. Truly human beings can choose to die not only for reasons of love and loyalty, but just because life happens to be too sour or bare.

J. FLETCHER, supra note 213, at 174 .

234. See Hume, On Suicide, in Ethical Issues IN DEATH AND DyING, supra note 230, at 109. 10 ("A man who retires from life does no harm to society; He only ceases to do good, which if it is an injury, is of the lowest kind."); P. LANDSBERG, THE ExPERIENCE of Death: THE MORAL PROBLEM OF SUICIDE 83-84 (1953) (the public welfare argument "may be valid in certain cases, where someone may in fact be abandoning an important social duty, but it is clearly inadequate as a general argument against suicide as such.").

235. Engelhardt \& Malloy, Suicide and Assisting Suicide: A Critique of Legal Sanctions, $36 \mathrm{Sw}$. L.J. 1003, 1010-11 (1982) (presenting the "libertarian" view that individuals should not, in general, be forced to assume social obligations and that restrictions on individual liberty should be limited to 
Finally, the argument that a suicide wrongs her friends and family is refuted by arguments resembling those used to refute the state interest in protecting innocent third parties. ${ }^{236}$ The obligation not to hurt friends and family is contingent on there being people who will be hurt, and so cannot entail that suicide is wrong in itself. Some suicidal people may have no dependents or close friends. Indeed, it is the elderly and the isolated who are most likely to commit suicide. ${ }^{237}$

These counterarguments, of course, do not prove that suicide is right in all circumstances, nor do they decisively refute the position that suicide is always wrong. They do, however, challenge the categorical moral condemnation of suicide, and suggest that courts should not rely on moral disapproval as an unquestioned foundation for the state interest in preventing suicide.

The evolution of suicide laws reflect challenges to the traditional moral condemnation of suicide. Suicide was a crime at English common law, was considered a form of murder, and was punishable by ignomimous burial and forfeiture of the suicide's property to the state. Attempted suicide and assistance to suicide also were crimes. ${ }^{238}$ Although the rationale for this view varied, preventing offense to God and to society predominated. ${ }^{239}$ Suicide was never a crime in American law, apparently because the prohibition was considered useless for preventing suicide and unjust to surviving relatives. ${ }^{240}$ However, attempting suicide was a crime in some jurisdictions, and assisting suicide was uniformly considered criminal. ${ }^{241}$

Currently, attempted suicide is not a crime $m$ any state, ${ }^{242}$ but the status of assisting suicide varies. In most states, aiding or causing suicide

the minimum conditions for ensuring equal hiberty for everyone); see supra text accompanying notes $159-60$.

236. See supra text accompanying notes 175-74.

237. Marzen, O'Dowd, Crone \& Balch, supra note 194, at 4.

238. See In re Joseph G., 34 Cal. 3d 429, 433-34, 667 P.2d 1176, 1178-79, 194 Cal. Rptr. 163, 165-66 (1983) (leading California case reviewing the legal status of suicide and assisting suicide); $G$. WilliaMS, supra note 208, at 257-64, 273-74, 296-99; Marzen, O'Dowd, Crone \& Balch, supra note 194, at 62-63. However, the penalty of ignominious burial and forfeiture has been considered excessively harsh for centuries, and coroner's juries regularly avoided its infliction by returning verdicts of suicide while temporarily insane. G. WiLLIAMS, supra, at 262-63; Marzen, O'Dowd, Crone \& Balch, supra, at 61.

239. G. Williams, supra note 208, at 258, 274-75; Marzen, O'Dowd, Crone \& Balch, supra note 194 , at $56-63$.

240. Marzen, O'Dowd, Crone \& Balch, supra note 194, at $69-70$.

241. Id. at 71-94.

242. Joseph G., 34 Cal. 3d at 433, 667 P.2d at 1178, 194 Cal. Rptr. at 165. The drafters of the Model Penal Code concluded that punishment is ineffective to deter attempted suicide. Therefore, the Code does not criminalize attempted suicide, but does criminalize "aiding or soliciting suicide." MOdel PeNAL CODE § 210.5(2) (Official Draft \& Revised Commentaries 1980). The drafters noted, however, that "[s] elf-destruction is surely not conduct to be encouraged or taken lightly." Id. comment 5. 
is punishable either as a form of murder or manslaughter, or as a unique offense. ${ }^{243}$ Many states have civil statutes providing for temporary commitment to a mental hospital of some persons who have attempted suicide. ${ }^{244}$ There is also a common law privilege to use reasonable force to prevent suicide, and it is never a legal wrong to stop someone from committing suicide. ${ }^{245}$ Overall, the legal history shows a trend towards treating the person who attempts suicide as someone who may need help and even coercive interference, but not as a criminal. ${ }^{246}$

The law thus no longer reflects a moral consensus that suicide is categorically wrong. ${ }^{247}$ Suicide laws have gradually changed, and further, the jurisprudential arguments against other state interests used in the refusal of treatment cases suggest that a state policy against suicide cannot be soundly based on moral disapproval. A state policy of preventing suicide still exists, however, and there is no legal right to commit suicide. But if this policy has a legitimate basis, it must be something other than the bare assertion that suicide is wrong per se.

\section{B. A Contemporary Basis for Preventing Suicide: Autonomy}

In trying to articulate a valid rationale for the state policy against suicide, courts should shift away froin inquiring whether suicide is right or wrong. Instead, they should ask whether each person should have an unhindered right to decide about the morality and desirability of suicide for herself. Even though there inay be persuasive arguments that suicide is not wrong in certain circumstances, it does not necessarily follow that there should be a legal right to commit suicide. Moral disapproval alone is a dubious basis for the state policy, but there nay be other reasons for the law to discourage suicide by allowing intervention. ${ }^{248}$ These other

243. Note, Criminal Liability for Assisting Suicide, 86 Colum. L. REv. 348, 350-53 (1986).

244. See, e.g., N.J. STAT. ANN. §30:4-26.3a (West 1981) (subjecting suicide attempters to temporary hospitalization when mental illness is suggested or the person's behavior poses a danger to life, persons, or property). This statute was cited by the Conroy court as evidence of the "legislative policy of preventing suicide." In re Conroy, 98 N.J. 321, 350, 486 A.2d 1209, 1224 (1985).

245. State v. Hembd, 305 Minn. 120, 130, 232 N.W.2d 872, 878 (1975); Byrn, supra note 199, at 16.

246. Joseph G., 34 Cal. 3d at 433-34, 667 P.2d at 1178-79, 194 Cal. Rptr. at 165-66 (criminal law "irrelevant" to the question of suicide); Commonwealth v. Wright, $26 \mathrm{~Pa}$. C. 666, 669 (1902) (suicide is not a crime because it results from mental disease).

247. Cole v. Combined Ins. Co. of Am., 125 N.H. 395, 397-98, 480 A.2d 178, 180 (1984).

248. This discussion of suicide intervention concerns coercive, as opposed to persuasive, intervention. Participants in the moral and legal debate over suicide generally agree that it is never wrong to attempt to persuade a suicidal person to change her mind. The point of disagreement is when, if ever, such a person should be forcibly restrained from immediate self-destruction, to gain time in which she might change her mind. See J. Glover, Causing Death and SAving Lives 177 (1977); G. WILLIAMS, supra note 208, at 290; Annas, supra note 10, at 21, 46. 
reasons concern the question of the competence of rash suicide attempters who, if restrained, would be glad to live.

There are at least three possible policies regarding suicide intervention, each with its own basis. First, a policy of maximum restraint is recoininended by the view that no suicides are competent or morally permissible. Second, a pohicy of temporary restraint is recommended by the view that suicide is not necessarily wrong or irrational in itself, but that most people who atteinpt suicide are incompetent or irresponsible. Such a policy would prevent all suicides except those of people who are coinpetent and determined to die. Finally, a policy of intervening only in obviously irrational suicide attempts is recommended by the view that suicide should be a inatter of personal moral choice.

Each of these three policies can best be expressed in terms of its own coinpetence test: The first assumes that there is no such thing as a coinpetent suicidal person; the second, that people who attenpt suicide should be presumed incompetent; and the third, that people who attempt suicide should be presumed competent.

The first pohicy is not viable. Reasonable people disagree on the 1norahity and desirability of suicide. Clearly, competent suicides can exist-people who have thought througl1 the ethical and personal questions and calmly decided to end a life of intolerable suffering. Further, even if all apparently rational justifications of suicide really are inere delusions and suicide is always inorally wrong, the prolonged forcible restraint of someone who is determined to commit suicide still may not be justified. 249

There are inore inoderate policy alternatives that fall between an absolute prohibition of suicide and an absolute right to suicide. Even commentators who generally support state intervention in suicide atteinpts concede that if someone calmly and steadfastly determines to die, she should ultimately be allowed to do so. ${ }^{250}$ Similarly, those who advocate a right to suicide usually support only a right to rational suicide. ${ }^{251}$ Thus, participants in the legal debate over suicide all agree that coinpetent, determined persons should not be coercively restrained froin coinnitting suicide, and that irrational suicides should be prevented. It is therefore misleading to cast the issue in terms of a "right" to suicide. ${ }^{252}$

249. J. GlOVER, supra note 248 , at 180.

250. See id. at 176-77; G. WILliams, supra note 208, at 293; Cantor, supra note 108, at 258 \& n.153.

251. See, e.g., Engelhardt \& Malloy, supra note 235, at 1036 \& n.157.

252. Marzen, O'Dowd, Crone \& Balch, supra note 194, at 106-07. These authors conclude:

To assert the existence of a constitutional right to suicide for "the emotionally and mentally untroubled person with good reasons to commit suicide" makes no jurisprudential sense. If suicide is to be deemed a right at all, then no prior proof of mental competence can be required and no presumption of mental or emotional instability can be 
The real disagreement concerns the majority of situations that fall between these clear cases: should the state presume the suicide attempter incompetent and restrain her, or presume her competent and leave her alone?

Empirical evidence supports the presumption of incompetence. Studies indicate that most suicides are nonautonomous-that is, not motivated by an unambiguous, settled desire to die. ${ }^{253}$ This evidence suggests that the pertinent policy question is which of two evils is the lesser: allowing the many nonautonomous suicide attempters to die when they might be (and may want to be) saved, or temporarily frustrating the few autonomous suicide attempters?

There are two reasons why the latter might be the lesser evil. First, a paternahistic view suggests that it is permissible temporarily to curtail mdividual liberty for the sake of preventing unnecessary and irrational self-harm. Second, the idea of social interdependence implies both that there is a moral duty to save the hives of nonautonomous suicides, and that nobody can claim an absolute right to commit certaim "private" acts, mcluding autonomous suicide.

Arguing that paternahistic intervention with suicide attempts is justifiable, one group of commentators has noted that the idea of the "right to suicide" misleadingly "evokes the image of the philosopher imbibing hemlock in the face of inevitable death and after a careful and agonizing decisionmaking process."254 Clearly most people who would attempt to exercise such a "right" would not do so in a singleminded, calm effort to end their lives. Many suicides are impulsive; if the attempt is frustrated, the person may go on to lead a satisfying life. Other suicides are not so much attempts at self-destruction as calls for help, attempts to change a social situation, or attempts to commumicate with a particular person. ${ }^{255}$ Since tliese suicides "are carried forward in an atmosphere of ambivalence and confusion, ... . [and] are intended to effect some purpose other than self-destruction," nonintervention in such attempts might paradoxically show disrespect for the true intentions of the attempters. ${ }^{256}$ To focus only on the apparent intention to kill oneself and ignore the complex reasons for attempting to do so is an arbitrary oversimplification,

attached to suicide. ... [A]ll persons would logically be free to commit suicide-whether

"rational" or not ... without state interference.

Id. at 106.

253. G. WILliams, supra note 208, at 283-86; Beauchamp, supra note 228, at 98; Marzen, O'Dowd, Crone \& Balch, supra note 194, at 122-39.

254. Marzen, O'Dowd, Crone \& Balch, supra note 194, at 107.

255. Id. at 122-27; see G. WILLIAMS, supra note 208, at 292-93; Beauchamp, supra note 228, at 98.

256. Marzen, O’Dowd, Crone \& Balch, supra note 194, at 10-11; see G. WILliams, supra note 208, at 283-86; Schulman, Suicide and Suicide Prevention: A Legal Analysis, 54 A.B.A. J. 855, 858 (1968). 
not a demonstration of respect for autonomy. A more thoughtful view would require that we free suicide attempters from the effects of their transitory and ambivalent self-destructive impulses, not leave them free to kill themselves.

Thus, paternatistic intervention with nonautonomous suicide attempts may well be compatible with the value of autonomy. Laws permitting suicide intervention are consistent with legitimate exercises of paternahism in other contexts. ${ }^{257}$ Further, even though laws designed to temporarily restrain nonautonomous suicides may also interfere with autonomous suicides, they do not severely deprive autonomous suicides of their liberty. Those who are genuinely resolved to die can make another attempt. ${ }^{258}$

However, the argument that paternalistic intervention is justified because most suicides are irrational assuines that we can tell whether a person's opimon that her life is not worth hiving is reasonable. ${ }^{259}$ Since it may not be possible to prove that our evaluation is objectively better than her own, there is a danger of arbitrarily depriving her of the authority to make her own inoral decisions. Consequently, tlie paternahistic argument that intervention is necessary to prevent nonautonomous suicides must be carefully circumscribed, or it miglit become a rationalization for misusing the competence determination to veto refusals of treatment that offend a particular judge.

The second source of support for a policy of suicide intervention based on a presumption of incompetence is an appeal to the idea of social interdependence. There is no sucli thing as a completely private action; as one judge has said, the "distinction between instances of harm to others and imstances of harm solely to self ... would seem rarely if ever to be relevant in actuahty because others are affected by virtually any

257. In Paris Adult Theatre I v. Slaton, 413 U.S. 49 (1973) the Supreme Court, citing such "constitutionally unchallenged" laws as those against suicide and self-mutilation, stated that "for us to say that our Constitution incorporates the proposition that conduct involving consenting adults only is always beyond state regulation, is a step that we are unwilling to take." Id. at 68 \& n.15 (footnote omitted). Also, Bym interprets Roe v. Wade, 410 U.S. 113 (1973), as having recognized, in addition to concerns with the protection of others, "a paternalistic interest in the protection of an individual against himself or herself. ... [T] [Te state may forbid an individual to engage in conduct which is hazardous to that individual's life or health," such as prohibiting third-trimester abortions or the handling of poisonous snakes, or compelling motorcyclists to wear helmets. Byrn, supra note 199, at 7; see also H.L.A. HART, LAW, LIBERTY, AND MORALITY 31-33 (1963) ("[P]aternalismthe protection of people against themselves-is a perfectly coherent policy. . . . [There is] a general decline in the belief that individuals know their own interest best, and . . . an increased awareness of a great range of factors which diminish the signifieance to be attached to an apparently free choice or to consent.").

258. J. GLOVER, supra note 248, at 176-77; see also Schulman, supra note 256 , at 862 ("Pragmatically, what seems to occur is that people are prevented from suicide and are thankful; if not thankful, they only try again, often succeeding.").

259. Engelhardt \& Malloy, supra note 235, at 1007-08 \& n.10. 
action which an individual takes or fails to take."260 This argument undermines the view that since suicides are not harming anyone but themselves, they have a right to be left alone. Just because a suicide does not directly harm anyone else does not mean that we should recognize an absolute right to commit suicide.

Conversely, just as the suicide attempter's conduct affects others, "the ideal of the atomistic imdividual freely and dispassionately making life and death choices free of societal influence is a myth."261 Many people commit suicide because of poverty, isolation, or social discrimination agamst the elderly and handicapped. ${ }^{262}$ Granting these people a right to die is an irresponsible substitute for an attempt to improve the conditions of their lives. ${ }^{263}$

Botli arguments for suicide intervention, however, conflict with the respect for autonomy embodied in both the common law protection of bodily self-determination and the constitutional right of privacy. The argument that no action is completely private is obviously at odds with the idea of a zone of privacy. ${ }^{264}$ Even if society is indirectly affected by an attempted suicide, it is not self-evident that society's interest should outweigh that of the person who is directly affected. This point is forcefully made by John Stuart Mill's famous statement that each person "is the proper guardian of his own health, whether bodily or mental and spiritual," and that "[m]ankind are greater gainers by suffering each other to hive as seems good to themselves than by compelling each to live as seems good to the rest."265

Further, the idea that the state has a duty to protect disadvantaged people from self-destructive despair conflicts with the common-law right

260. Winters v. Miller, 446 F.2d 65, 73-74 (2d Cir.) (Moore, J., concurring in part and dissenting in part), cert. denied, 404 U.S. 985 (1971).

261. Marzen, O'Dowd, Crone \& Balch, supra note 194, at 147 . The authors continue:

To the lone elderly occupant of a nursing home, to the frustrated individual incapacitated by handicap and moved to the margins of society by discrimination, to the despondent person immobilized by a life crisis, societal affirmation of the 'right' to suicidc is less likely to be seen as an ennobling enhancement of personal dignity than a clear signal of indifference: the community does not care whether he or she lives or dies.

Id.

262. Id. at 4, 127-36 (citing illness, poverty, occupational stress, and isolation as social causes of suicide).

263. In discussing Bouvia v, County of Riverside, Marzen, O'Dowd, Crone and Balch comment that ill and disabled people may commit suicide not only because of their affictions, but because of "the rejection they suffer from others." Id. at 132. If this rejection were replaced by support and acceptance, their choice to commit suicide might be reversed.

264. See supra notes 125-26 and accompanying text.

265. J.S. MiLL, ON LiberTy 72 (Pelican ed. 1974) (1st ed. 1859). This idea is echoed in Cardozo's famous statement that "[t]he judge ... is not to innovate at pleasure. He is not a knighterrant roaming at will in pursuit of his own ideal of beauty or of goodness." Hence, judges cannot deny individuals the right to act in ways that may be morally offensive, but are not unlawful. $B$. Cardozo, The Nature of the Judicial Process 141 (1921). 
of self-determination. ${ }^{266}$ The view that some people-such as the elderly, the poor, and the isolated - are particularly vulnerable to psychological and social pressures, and therefore must be protected for their own good, may overlook their liberty and dignity. A paternalistic policy may imply that such people are unfit to control their own hives, thus encouraging precisely the kind of dehumanization and social rejection that drives many people to suicide in the first place.

Arguments that a general policy of intervention is justified by the nonautonomous characteristics of many suicide attempts are persuasive. The potential affront of such a policy to autonomy and imdependent moral judgnient is outweighed by its potential both for saving the lives of many nonautonomous, impulsive suicide attempters and for heeding the calls for help that many suicide attempts represent. ${ }^{267}$ This potential justifies such a temporary deprivation of hiberty. Before setting a person free to die, society should try to set her free to hive by seeking to reheve her despair and helplessness. Legal provisions for temporary restraimt and counseling are an acceptable compromise between the values of autonomy and self-determination on the one hand, and compassion and social responsibility on the other. ${ }^{268}$

This reasoning, however, supports only a presumption of incompetence, not unlimited coercive imterference. The best justification for intervention is that the suicide attempter is probably acting hastily, overcome by transitory despair. If it becomes clear that a person is not acting out of such nonautonomous motives, contmued intervention is unjustified. It is difficult to draw the lime between legitimate intervention and

266. In Zant v. Prevatte, 248 Ga. 832, 286 S.E.2d 715 (1982), the Georgia Supreme Court held that the state could not intervene in a politically motivated suicide: "The State . . . has no right to destroy a person's will by frustrating his attempt to die if necessary to make a point." Id. at 834,286 S.E.2d at 716-17; see also Engelhardt \& Malloy, supra note 235, at 1033 n.151 ("The determination of one's own life, including suicide and assisting suicide, is a private matter and should not be interfered with simply because it occasions public moral outrage.").

267. One group of commentators reply to the idea that we should not second-guess someone's judgment about the value of her own life by referring to psychological evidence that stress and depression impair cognition and judgment. Thus, "one mood is not, for purposes of rational decision-making, as valid as another," and others are sometimes better able to evaluate a person's situation than she is herself. Marzen, O'Dowd, Crone \& Balch, supra note 194, at 120.

268. This conclusion comports with common-sense responses to suicide. As Williams points out:

The natural and human thing to do with a person who is suddenly discovered attempting suicide is to interpose to prevent it. ... Following the frustration of the attempt, there may have to be some temporary restraint or surveillance while it is considered whether the attempter can be medically treated or dissuaded from the attempt . . . .

A very short time limit should be placed on the detention order . . . . Ultimately, society cannot stop a free man from committing suicide, nor should it try. What can be done is to make sure that the determination upon self-destruction is fixed and unalterable.

G. WilliaMS, supra note 208, at 292-93. See also Annas, supra note 10, at 21 ("If we simply accept [the patient's decision to die], it is argued, we devalue all severely handicapped persons. But surely there is a middle ground between 'simply accepting' her decision, and violently force-feeding her."). 
either moralistic second-guessing of a person's genuinely autonomous decision to die, or deineaning restraints that treat certain social groups as less autonomous than others.

\section{The Competence Dilemma}

The problem of determining competence, generally a difficult issue in informed consent doctrine, thus becomes crucial in defining a policy concerning when to stop restraining a would-be suicide. If the paternalisin and social interdependence arguinents are to legitimate the state policy against suicide, they must yield a competence test adapted to the problems of suicidal refusal. The legitimate state interest in preventing suicide is an interest in preventing "incoinpetent" suicides. To determine whether or not this imterest is imphicated in a particular case, courts should examine the competence of the patient with a specific focus on the problem of nonautonomous suicide. Thus, two probleins discussed earher, the competence dilemma, ${ }^{269}$ and the inadequacy of the balancing test in the context of suicidal refusals, ${ }^{270}$ become intertwined.

The suicidal refusal problem creates a more acute version of the competence dilenma. When a patient's refusal of treatment appears suicidal, the court cannot simply base its decision on the objective reasonableness of the refusal, for that would reduce the competence inquiry to the judge's quahtative evaluation of the patient's decision. Moreover, if the suicidal nature of the patient's decision were to constitute conclusive evidence of incompetence, then the patient's right to refuse treatment would be flatly denied. On the other hand, the judge can hardly disregard the facts that the decision will result in the patient's death and that this appears to be the patient's purpose. These circumstances make it particularly hard to determine whether the decision represents a nonautonomous suicide that the state has a legitimate interest in preventing. The suicidal nature of the patient's decision to refuse treatment should not be dispositive, but neither should it be irrelevant.

Courts inust make a subtle qualitative distinction between patients who are generally able to make decisions but made a "bad" decision this time and patients who lack decisionmaking ability. ${ }^{271}$ In differentiating between the two, courts should examine the reasons why the patient's decision is opposed by her family or doctors, and why her competence has been challenged. If these reasons concern the patient's general inental capacity, or the conditions under which the patient decided to refuse treatment-such as haste, pain, shock, or depression, or self-delusion

269. See supra text accompanying notes 141-52.

270. See supra text accompanying notes 222-29.

271. The distinction is like the difference between making a strategic error in a game and not knowing how to play that game. 
about relevant facts-then they may support a finding of incompetence. ${ }^{272}$ But if the reasons reduce to a value disagreement, such as over what degree of pain or disability makes life not worth living or when to give up on elaborate treatments with hittle chance of success, ${ }^{273}$ then there is no legitimate basis for a finding of incompetence.

VII

\section{A Proposed Test for Suicidal Competence}

Suicidal imtent is not a sufficient reason to deny a patient the right to refuse treatment. The criminality or moral wrongfulness of suicide is no longer essential to either the state pohicy against suicide or the moral conflict about suicide intervention. Instead, the policy debate focuses on balancing concerns about justified paternahsm and social interdependence with concerns about patient autonomy and self-determination. The judicial determination about whether to override a patient's suicidal refusal of treatment must accommodate both these sets of concerns, and courts should not use analytically rigid distinctions to evade making such determinations. Rather, courts should expand their analysis in refusal of treatment case to take account of the state's interest in preventing suicide.

Since the state's interest in preventing suicide is better supported by a concern for nonautonomous suicides than by a categorical inoral disapproval of suicide, suicide prevention policy should be oriented toward short-term efforts to prevent incompetent suicides, and not toward interventions so invasive that they attempt to block even rational and deterinined suicides. The presumption that a person who attempts suicide is incompetent, and so may be restrained for her own good, is justified by empirical evidence and a balanced accommodation of the values of autonomy and social responsibility. To guard against unwarranted infringements on personal autonomy, however, the presumption of incompetence must be both temporary and rebuttable by evidence of the patient's general ability to make rational decisions. As in the informed consent doctrine, persistence in making a "wrong" decision should not be equated with incompetence.

272. See Tepper \& Kaslow, Informed Decision-Making Capacity: A Patient's Ability to Participate in Treatment Determinations, 6 LAw \& Psychology Rev. 49, 50-51 (1981) (arguing that capacity for informed decisionmaking depends on interpersonal cognitive problem-solving skills, including "the capacity to generate alternative solutions to problems" and "the ability to consider the [interpersonal] consequences of one's social acts").

273. However, substantial discrepancies between the patient's evaluations and those of the family, doctors, or the court are relevant evidence in a determination of competence. The point is that, standing alone, they must not be regarded as conclusive on the competence issue. 


\section{A. The Test}

The state interest in preventing incoinpetent suicides is compelling. To determine whether that interest is implicated in a given case, courts should be guided by two considerations:

(1) Whether the patient's refusal is a reflective, settled decision, consistent with the patient's general way of life or religious or philosophical convictions; or alternatively, a hasty decision inade in reaction to a sudden personal catastrophe, temporary severe depression, or a mental impairment due to pain, disease, or the side effects of medication.

(2) Whether the patient's probable future life will be so diminished in quality that a reasonable person could conclude that it is not worth living; or alternatively, the patient's life could be valuable and fulfilling, thus raising doubt about whether the patient appreciates the prospects she is renouncing.

If the patient's decision is hasty and her potential life appears valuable, then the state's interest in preventing suicide justifies state restrictions on the patient's right to refuse treatment. Conclusive denial of that right is still not justified, however, because the state's legitimate interest is limited to the prevention of incoinpetent suicides.

When a court determines that a patient has decided hastily to cut short a potentially long and rich life without a background of consistent religious or philosophical convictions that might justify that decision, it should presume her incoinpetent. ${ }^{274}$ It can then impose procedural restrictions on the right to refuse treatment. The court should limit nonconsensual medical treatment to such treatment as is necessary to sustain life and preserve the patient's ability to reconsider the treatment decision. ${ }^{275}$ Attentive nursing care and counseling should also be offered, on a noncoercive basis. These restrictions on the right to refuse treatment give the patient an opportunity to reconsider and the health care staff and the patient's family a chance to understand the patient's reasons and

274. Cantor proposes temporary restraint to resolve the problem of suicidal refusal of treatment. Cantor, supra note 108, at 258 ("temporary intervention to provide psychological assistance (and medical treatment if the patient would die in the interim) is warranted ..... If the patient demonstrates [competence], however, and persists in refusal of treatment, that decision should be respected.").

This Comment argues that both the state's temporary intervention and the patient's ultimate right to persist in refusing treatment can be justified by the interplay of the state's iuterest in preventing suicide and the patient's interests on which the right to refuse treatment is based.

275. In some cases, however, it may be impossible to keep the patient physically fit to make decisions while still preserving her options of accepting or refusing treatment, either because any effective temporary treatment will cure the life-threatening condition, or because any delay will make later treatment useless. In such cases, if there is no time to verify that the patient's decision is wellconsidered, doctors should err on the side of preserving her life. 
to express their concern and willingness to help. ${ }^{276}$ But if the patient reaffirms her refusal of treatment, the presumption of incoinpetence is overcoine and the state's interest in preventing suicide does not justify further intervention.

This revised balancing test, incorporating the two proposed considerations on suicidal refusal, creates a danger of moralistic, subjective interference with the patient's decision. It requires the court to assess the quality of the patient's decisionmaking and to weigh the potential value of her future life. Because of the competence dilemma, especially the intractable version of it created by the suicidal refusal issue, there simply is no way to avoid this latter substantive evaluation, except by making the right to refuse treatment absolute. This latter possibility is unacceptable because it sacrifices the lives of patients whose decisions are ill-considered out of excessive hesitancy to make value judgments or to restrict patients' autonomy. Solicitude for the right to die could too easily becoine an excuse not to work to improve these patients' conditions of living.

Moreover, if some quahtative evaluation is inevitable, it is better that it be explicit and limited, rather than hidden and arbitrary. The two proposed considerations come into play only if the patient's refusal is opposed by her family or doctors, appears suicidal, and presents no special circuinstances that imphicate other compelling state interests. ${ }^{277}$ Therefore, they do not apply, and thus they create no risk of excessive judicial intervention, in many refusal of treatinent cases. And even if the court finds the state interest in preventing suicide is implicated, this interest does not create an absolute barrier to the right to refuse treatment. At most, the patient must overcome an additional procedural hurdle. It is better to risk the temporary indignity of moralistic intervention than to abdicate social responsibility for preventing nonautonomous suicidal refusals.

This temporary indignity is hardly insignificant. The Bouvia court

276. However, a balance must be maintained between humane intervention and disrespect for the patient's autonomy. In connection with Elizabeth Bouvia's 1983 case, Annas comments:

There seems to be a societal presumption that individuals who attempt to kill themselves must be incompetent. Since one cannot properly assess competence on a ledge or on a bridge, reasonable steps to prevent a public suicide seem justified.

Similarly, it seems perfectly reasonable for health professionals . . . to try to prevent the suicide ... . Reasonable steps can and should be taken to assess [Bouvia's] competence and dissuade her from self-destruction. But where do reasonable and required steps end, and unreasonable and unconscionable actions begin?

Annas, supra note 10, at 21. Annas argues that hospitals should continue "efforts at persuading the individual to change his or her mind, and offering oral nutrition" in situations like Bouvia's. Id. at 46.

277. For a discussion of the state's interests in preserving life, protecting innocent third parties, and protecting medical integrity, see supra text accompanying notes 153-83. 
stated that "justice delayed is justice denied."278 The special procedures proposed above may seem a bureaucratic obstacle course set in the path of patients' exercise of a fundamental right. The statement in Bouvia, however, referred to the months of delay resulting from the trial court's demial of her request, and her appeal. If the procedure proposed here were implemented at the trial court level and its results were generally accepted by the medical profession, it would create far less delay than Bouvia experienced, and would avoid the extremes of either an absolute denial of the patient's right to refuse treatment, or an unfettered right to refuse. Moreover, a delay to ensure that the patient's decision is settled and not reversible by others' efforts to help can be seen, even by a patient determined to die, as an expression of care and concern, not insensitivity to her viewpoint and desires.

\section{B. Illustrations}

Refusals of specific kinds of treatment based on religious principles would generally lie beyond the scope of the state interest in preventing suicide. They represent deliberate and sincere decisions based on an ongoing way of life, motivated not by despair but by faith. ${ }^{279}$ In many otlier refusal of treatment cases, however, the state interest in preventing suicide might be compelling. Consider the following hypothetical cases:

(1) An elderly patient, wlo is poor and lives alone, is brouglit to a hospital with severe and potentially fatal pneumonia. She refuses to take antibiotics, knowing that lier refusal will result in death, stating that slie is lonely and tired of living.

(2) A middle-aged patient is informed that he has incurable cancer. With an operation, he will probably live at least a year without severe pain, but will eventually die from the disease. Without the operation, he will certamly die soon. Shocked and depressed at lis fatal illness, lie refuses the operation, seeing it as useless.

(3) A young athlete suffers an accident that leaves him severely disabled, but inentally undamaged. He refuses treatment to ward off a fatal infection because lie sees no purpose in living now that his athletic career is over.

278. Bouvia v. Superior Court, 179 Cal. App. 3d 1127, 1135, 225 Cal. Rptr. 297, 299 (1986).

279. For example, the patient in John F. Kennedy Memorial Hosp. v. Heston, 58 N.J. 576, 279 A.2d 670 (1971) had carried a card in her wallet for six years that stated her decision not to accept blood transfusions. Note, supra note 199, at 587. Likewise, some non-religious refusals may result from "principled" fidelity to deeply held philosophical views. Cantor does not distinguish between religious and other principled refusals: "Most instances of refusal represent careful decisions to abide by religious or philosophical principles, and not rash attempts at self-destruction." Cantor, supra note 108, at 257. 
In all these cases, a court could find the patient competent at the threshhold level, and the state interests in preserving life, protecting third parties, and protecting medical integrity no more compelling than in the cases so far decided. The court could decide that these patients' refusals are not suicides-and so do not implicate the state's interest in preventing suicide-on the technical grounds that they lack the specific intent to die or that their passive refusals of treatment are not acts of suicide. Thus, using the current doctrinal approach, courts might allow all three of these patients to refuse lifesaving treatment.

In contrast, a court using the test proposed here could find that these patients' decisions are hasty and that the lives they are attempting to sacrifice are valuable. Temporary restraint would then be appropriate. The waiting period, care, and an opportunity for counseling and family support might influence patients such as these to reconsider. If they do not, then these patients' right to refuse treatment ultimately would prevail.

The proposals made here might not change the result in a case like Bouvia. Patients like Bouvia, who consistently reject nonemergency treatment, and thus have ample opportumity to reconsider their decisions, might pass through any reasonable procedure of temporary restrictions and thus overcome the presumption of incompetence arising in cases of suicidal refusal. ${ }^{280}$ Yet the fact that even Bouvia appears to have changed her $\min \mathrm{d}^{281}$ indicates the need for temporary restramt and a focused and orderly procedure to test the firmness of the suicidal patient's decision to refuse treatment. The possibility that offers of care and assistance and time to reconsider might dissuade even an apparently deternmed patient from her decision to die should not be left to the contingencies of the legal process.

\section{CONCLUSION}

Existing refusal of treatment cases leave undefined the scope and limits of the patient's right to refuse treatment. This right derives from interests in autonomy and privacy that have not been adequately articulated by the courts. The patient's right to refuse treatment is limited both by the requirement that she be competent and by countervailimg state interests, including an interest in preventing suicide. No state inter-

280. Glover argues that the justifications for suicide prevention efforts do not extend to interventions such as force-feeding. In such situations the suicidal person has ample time to reconsider, and the pain and humiliation caused by the method of intervention are greater than for other short-term efforts at suicide prevention. J. GLOVER, supra note 248, at 177.

281. See supra note 2 and accompanying text. It may be that she did not change her mind, and that she did not want to die in the first place, but only to be allowed to die. 
est, however, has been found categorically to outweigh the patient's right.

In future cases, courts should take the state interest in preventing suicide more seriously, rejecting overly technical distinctions between refusal of treatment and suicide in favor of substantive analysis of the tension between the autonomy of the patient and the protective responsibilities of the state. The state's legitimate interest in preventing rash, incompetent suicides should be balanced against the patient's right to refuse treatment. To achieve this balance, courts should teinporarily restrain patients whose refusals appear suicidal to ascertain whether they are clearly and calmly determined to die.

A inore thoughtful inquiry into the patient's competence is the key to resolving the suicidal refusal problem. The values underlying the right to refuse treatment support ouly competent refusal, and conversely, the justification for the state imterest in preventing suicide limits that interest to the prevention of incompetent suicides. Thus, the decisive question is whether an arguably suicidal patient is competent. In answering this question, courts should carefully distinguish evidence of inpaired decisionmaking capacity from evidence that the patient's decision is guided by unorthodox concerns and values.

Elizabeth Bouvia's initial decision to refuse treatment may be considered unwise or even tragic. Those who were involved in her case beheved that she was making a wrong choice and that her life was worth preserving. ${ }^{282}$ However, they were right to argue that she had no legal duty to endure a life she found unendurable. ${ }^{283}$ In future cases courts should employ a balancing process, like the test proposed here, that reaches the substance of the state interest in preventing suicide. If that interest is compelling, then procedural safeguards should be imposed to ensure that the patient's decision is not the result of haste and despair and caunot be swayed by attention, compassion, and medical, economic, or psychological assistance. This would have been a better response to Bouvia's attempt to refuse treatment than either the trial court's rigid demal or the appellate court's unquestioning acceptance of her decision.

Martha Alys Matthews*

282. Heilman \& Thompson, supra note 12 , at 16.

283. See Annas, supra note 10, at 46 (quoting plaintiff's summation in Bouvia v. County of Riverside, No. 157280 (Cal. Super. Ct. Riverside Co., Dec. 16, 1983)).

* A.B. 1984, Swarthmore College; third-year student, Boalt Hall School of Law, University of California, Berkeley; Ph.D. student, Jurisprudence and Social Policy Program, University of California, Berkeley. 